Marquette University

e-Publications@Marquette

Biological Sciences Faculty Research and

Publications

Biological Sciences, Department of

$5-2014$

\title{
Context-Dependent Remodeling of Rad51-DNA Complexes by Srs2 Is Mediated by a Specific Protein-Protein Interaction
}

\author{
Anna K. Lytle \\ Utah State University \\ Sofia S. Origanti \\ Utah State University \\ Yupeng Qiu \\ University of Illinois at Urbana-Champaign \\ Jeffrey VonGermeten \\ Utah State University \\ Sua Myong \\ University of Illinois at Urbana-Champaign
}

See next page for additional authors

Follow this and additional works at: https://epublications.marquette.edu/bio_fac

Part of the Biology Commons

\section{Recommended Citation}

Lytle, Anna K.; Origanti, Sofia S.; Qiu, Yupeng; VonGermeten, Jeffrey; Myong, Sua; and Antony, Edwin, "Context-Dependent Remodeling of Rad51-DNA Complexes by Srs2 Is Mediated by a Specific Protein-Protein Interaction" (2014). Biological Sciences Faculty Research and Publications. 422.

https://epublications.marquette.edu/bio_fac/422 
Authors

Anna K. Lytle, Sofia S. Origanti, Yupeng Qiu, Jeffrey VonGermeten, Sua Myong, and Edwin Antony

This article is available at e-Publications@Marquette: https://epublications.marquette.edu/bio_fac/422 


\title{
Context Dependent Remodeling of Rad51-DNA Complexes by Srs2 Is Mediated by A Specific Protein- Protein Interaction
}

\author{
Anna K. Lytle \\ Department of Chemistry and Biochemistry \\ Utah State University \\ Logan, UT \\ Sofia S. Origanti \\ Department of Chemistry and Biochemistry \\ Utah State University \\ Logan, UT \\ Yupeng Qiu \\ Department of Bioengineering \\ University of Illinois at Urbana-Champaign \\ Champaign, IL \\ Jeffrey VonGermeten \\ Department of Chemistry and Biochemistry \\ Utah State University \\ Logan, UT
}




\author{
Sua Myong \\ Department of Bioengineering \\ Center for Biophysics and Computational Biology \\ Center of Physics for Living Cells, \\ University of Illinois at Urbana-Champaign \\ Champaign, IL \\ Edwin Antony \\ Department of Chemistry and Biochemistry \\ Utah State University \\ Logan, UT
}

\title{
Highlights:
}

- Rad51 bound on SsDNA is removed by the Srs2 helicase.

- Rad51 when bound on dsDNA inhibits the DNA unwinding activity of the Srs2 helicase.

- Assembly of more than one Srs2 molecule on DNA is required for its unwinding activity.

- A physical interaction between Srs2 and Rad51 regulates DNA unwinding.

Keywords: Srs2; DNA unwinding; Rad51; Homologous Recombination; Helicase; DNA Repair

Abstract: The yeast Srs2 helicase removes Rad51 nucleoprotein filaments from single-stranded DNA, preventing DNA strand invasion and exchange by homologous recombination. This activity requires a physical interaction between Srs2 and Rad51, which stimulates ATP turnover in the Rad51 nucleoprotein filament and causes dissociation of Rad51 from single-stranded DNA. Srs 2 also possess a DNA unwinding activity and here we show that assembly of more than one Srs 2 molecule on the $3^{\prime}$ ssDNA overhang is required to initiate DNA unwinding. When Rad51 is bound on the dsDNA, its interaction with Srs2 blocks the helicase (DNA unwinding) activity of Srs2. Thus, in different DNA contexts the physical interaction of Rad51 with Srs2 can either stimulate or inhibit the remodeling functions of Srs2, providing a means for tailoring DNA strand exchange activities to enhance the fidelity of recombination.

\section{Introduction}

Homologous recombination (HR) is an error-free pathway for the repair of DNA double strand breaks, and inherited deficiencies in $\mathrm{HR}$ proteins give rise to gross chromosomal rearrangements that are

Journal of Molecular Biology, Vol. 426, No. 9 (May 1, 2014): pg. 1883-1897. DOI. This article is (C) Elsevier and permission has been granted for this version to appear in e-Publications@Marquette. Elsevier does not grant permission for this article to be further copied/distributed or hosted elsewhere without the express permission from Elsevier. 
features of cancer and other diseases. ${ }^{1}$ The Rad51 recombinase promotes the pairing and exchange of homologous DNA strands by forming nucleoprotein filaments that catalyze the alignment of a broken DNA end with a homologous sequence that serves as a template for the repair of DNA double-strand breaks and inter-strand crosslinks. ${ }^{2}$ Positive and negative regulators of HR activity control the assembly and stability of Rad51 nucleoprotein filaments, and are essential for the maintenance of normal genomic structure. ${ }^{1}$

The yeast Srs2 protein is a superfamily-1 (SF-1) helicase/translocase that suppresses HR activity and is required for the stability of genomic DNA in Saccharomyces cerevisiae. ${ }^{3}$ In distinction to other prokaryotic SF-1 helicases, Srs2 has a unique C-terminal region of $\sim 400$ residues that interacts with several DNA replication and repair proteins. ${ }^{4 ; 5}$ Deletion of the C-terminal region from Srs2 eliminates the physical interaction with Rad51, impairing the antirecombinogenic functions of Srs $2.4 ; 5 ; 6$ We previously showed that the Srs2-Rad51 protein-protein interaction activates ATP hydrolysis within the Rad51 nucleoprotein filament and promotes Rad51 dissociation from single-stranded DNA, providing a mechanism for the suppression of HR activity. ${ }^{4}$ Srs 2 has several additional activities including translocation on single-stranded DNA (sSDNA) and unwinding of double-stranded DNA (dsDNA) ${ }^{4 ; 7}$ that in principle could limit HR activity and/or resolve dead-end products of DNA strand exchange.8;9

Additional biological roles for Srs2's DNA unwinding activity are being discovered. ${ }^{10 ; 11 ; 12}$ In addition to preventing recombination, Srs2 can influence the outcome of HR by promoting synthesis dependent strand annealing (SDSA) in preference to crossover products. ${ }^{8 ; 11 ; 12}$ Srs2 can also unwind triplex DNA structures in concert with DNA polymerase $\delta$, and thereby prevent the expansion of trinucleotide repeats. ${ }^{13 ; 14 ; 15}$ Yeast strains lacking Srs2 show a 40-fold increase in the rate of trinucleotide repeat expansion. ${ }^{13 ; 16}$ This activity appears to be independent of Rad51's function in HR, but requires ATP hydrolysis by Srs2, and presumably, its translocation on DNA. ${ }^{13}$ DNA translocation and unwinding activities of Srs2 may also assist cells in recovering from checkpoint-mediated arrest after the completion of double-strand break repair, perhaps by removing proteins from DNA to signal the completion of repair. ${ }^{17 ; 18}$

Journal of Molecular Biology, Vol. 426, No. 9 (May 1, 2014): pg. 1883-1897. DOI. This article is @ Elsevier and permission has been granted for this version to appear in e-Publications@Marquette. Elsevier does not grant permission for this article to be further copied/distributed or hosted elsewhere without the express permission from Elsevier. 
Given the importance of Srs2's C-terminal region for regulating HR functions such as the disassembly of Rad51 filaments, we investigated whether or not this region also influences the helicase activity of Srs2. Here, we report the unique C-terminal domain of Srs2 is dispensable for DNA unwinding activity, but functions to selectively block unwinding of dsDNA that is coated with Rad51. This surprising result indicates that the interaction of Srs2 with the Rad51 protein facilitates two different anti-recombinogenic functions of Srs2, promoting the disassembly of Rad51-ssDNA filaments and inhibiting the unwinding of branched DNA intermediates formed during HR.

\section{Results}

\section{Rad51 protects dsDNA from unwinding by Srs2}

In principle, the DNA unwinding activity of Srs2 could down regulate $\mathrm{HR}$ activity by dissociating branched DNAs and crossovers formed during recombination, ${ }^{19}$ in addition to preventing DNA strand exchange a priori by disassembling Rad51 filaments. ${ }^{5 ; 20}$ Here we examined the DNA substrate requirements and effects of Rad51 on the DNA unwinding activity of Srs2. Since the non-conserved C-terminal domain of Srs2 is required for efficient disassembly of Rad51 filaments on ssDNA ${ }^{4}$ we examined whether this C-terminal domain also contributes to DNA unwinding. Helicase activity was measured using a 25 base pair (bp) dsDNA substrate with a 3'-15 nt ssDNA flanking region to allow loading of Srs2 onto the DNA (see Methods). As described previously, ${ }^{4}$ the full-length Srs 2 protein is prone to severe aggregation and hence we examined $\mathrm{Srs}^{\mathrm{C} \Delta 276}$ (residues 1-898), which has all of the known Rad51-specific functions of Srs2, and a slightly smaller Srs2 ${ }^{\mathrm{C} \triangle 314}$ protein that does not interact with Rad51 and fails to clear Rad51 filaments from ssDNA. ${ }^{4}$ The Srs2 ${ }^{\mathrm{C} \Delta 276}$ and Srs2 ${ }^{\mathrm{C} \Delta 314}$ proteins are both efficient helicases in vitro (Figures $1 \mathrm{~A} \& 1 \mathrm{D}$ ). The Srs2 ${ }^{\mathrm{C} \triangle 314}$ protein fails to rescue the hyper-recombination phenotype of a yeast Srs 2 deletion strain, whereas a slightly longer construct (residues 1-875), similar to Srs2 $2^{\mathrm{C} \Delta 276}$ can partially complement the loss of Srs $2 .{ }^{6}$ These results indicate that the C-terminal region of Srs2 is not required for helicase activity in vitro, although it contributes to the regulation of $\mathrm{HR}$ functions in vivo.

Journal of Molecular Biology, Vol. 426, No. 9 (May 1, 2014): pg. 1883-1897. DOI. This article is (C) Elsevier and permission has been granted for this version to appear in e-Publications@Marquette. Elsevier does not grant permission for this article to be further copied/distributed or hosted elsewhere without the express permission from Elsevier. 
Although the C-terminal region of Srs2 is not required for DNA unwinding, we considered whether its interaction with Rad51 might alter DNA unwinding activity. Purified Rad51 protein was added to the DNA unwinding substrate before the addition of Srs2 (Figures 1B \& $1 \mathrm{E}$ ). Rad51 binds to the dsDNA substrate in a saturable manner (KD = $1.5 \pm 0.3 \mu \mathrm{M}$; Figure S1) and interferes with DNA unwinding by Srs2 ${ }^{\mathrm{C} \Delta 276}$ (Figures $1 \mathrm{~B} \& 1 \mathrm{C}$ ). However, Rad51 has no effect on the DNA unwinding activity of the shorter Srs $2^{\mathrm{C} \Delta 314}$ protein (Figures $1 \mathrm{E} \& 1 \mathrm{~F}$ ). Dupaigne et.al. reported that the DNA unwinding activity of full-length Srs 2 is stimulated by the addition of Rad51 and the single-strand binding protein RPA, ${ }^{11}$ instead of the suppression that we observe in the presence of Rad51. Although these authors studied full-length Srs2 protein using a longer DNA substrate (200 bp versus the 25 bp dsDNA used here) for their helicase assays, we suspected that the longer incubation time used by Dupaigne et.al. (15 min. versus $2 \mathrm{~min}$. in our studies) might allow Rad51 to dissociate from DNA and relieve the inhibition of DNA unwinding activity.

\section{Intrinsic dissociation of Rad51 from dsDNA permits unwinding by Srs2}

We therefore measured the steady-state rates of DNA unwinding under multiple turnover conditions, in the presence and absence of Rad51. Under steady-state conditions, the truncated Srs $2^{\mathrm{C} \triangle 314}$ protein unwound the DNA at a rate of $0.041 \pm 0.005 \mathrm{~min}^{-1}$, and the addition of Rad51 ( $45 \mathrm{nM}$ ) slowed the rate to $0.027 \pm 0.008$ $\min ^{-1}$ (Figures $2 \mathrm{~A}$ and $2 \mathrm{~B}$ ). The longer $\mathrm{Srs} 2^{\mathrm{C} \Delta 276}$ protein is completely inhibited by Rad51 during the first 5 minutes of the reaction (Figures $2 \mathrm{C}$ and 2D); however, after a significant lag, Srs2 ${ }^{\mathrm{C} \Delta 276}$ unwinds DNA at a rate $\left(0.043 \pm 0.004 \mathrm{~min}^{-1}\right)$ comparable to the initial rate of unwinding by Srs2 ${ }^{\mathrm{C} \Delta 314}$ (Figure $2 \mathrm{C}$ ). We also measured the kinetics of DNA binding by Rad51, which dissociates rapidly from a short $15 \mathrm{nt}$ ssDNA ( $t_{1 / 2}=0.1$ min; Figure $2 \mathrm{E}$ ); however, a longer lived Rad51 complex is formed on the DNA unwinding substrate $\left(t_{1 / 2}=13 \mathrm{~min}\right.$; Figure 2E). A comparable rate of human Rad51 dissociation from dsDNA has been reported $\left(t_{1 / 2} \sim 5 \mathrm{~min}\right){ }^{21}$ Thus, the observed lag period of several minutes before DNA unwinding activity is observed may be due to the slow dissociation of Rad51 from the dsDNA. However, the inhibitory effect of Rad51 on the DNA unwinding activity

Journal of Molecular Biology, Vol. 426, No. 9 (May 1, 2014): pg. 1883-1897. DOI. This article is @ Elsevier and permission has been granted for this version to appear in e-Publications@Marquette. Elsevier does not grant permission for this article to be further copied/distributed or hosted elsewhere without the express permission from Elsevier. 
of Srs2 ${ }^{\mathrm{C} \Delta 276}$, but not Srs2 $2^{\mathrm{C} \Delta 314}$, suggests that it is due to a specific protein-protein interaction with the Srs $2^{\mathrm{C} \Delta 276}$ protein, and not nonspecific stabilization of the DNA duplex by Rad51.

Since Srs2 and Rad51 physically interact in the absence of DNA, ${ }^{4 ; 5} 22$ we also considered the possibility that Rad51 inhibits DNA unwinding by forming a complex with free Srs2 in solution and preventing it from binding and loading onto the DNA. To address this possibility, we examined the DNA unwinding activity of Srs2 ${ }^{\mathrm{C} \Delta 276}$ in the presence of a mutant rad51-E221D protein that hydrolyzes ATP about 10-fold faster than wild-type Rad51 and consequently binds to DNA with very low affinity. ${ }^{4}$ The weak DNA binding activity of rad51E221D requires the single-stranded DNA tail of the DNA unwinding substrate and does not bind to a blunt-ended duplex (Figure S1). Although rad51-E221D stably interacts with the Srs2 protein in the absence of DNA, ${ }^{4}$ it does not inhibit the DNA unwinding activity of Srs $2^{\mathrm{C} \Delta 276}$ when rad51-E221D is present in large excess over DNA and Srs2 ${ }^{\mathrm{C} \Delta 276}$ (Figure $2 \mathrm{~F}$ ). These results indicate that the DNA bound form of Rad51 inhibits DNA unwinding by Srs2, but only in conjunction with the specific protein-protein interaction between Rad51 and the Cterminal region of Srs2.

The binding site size of Rad51 on SSDNA is roughly $3.3 \mathrm{nt}$. In our unwinding experiment, there are a total of $60 \mathrm{nM}$ Rad51 binding sites including both the 25 bp dsDNA region and the 15 nt 3' overhang. We measured the Rad51 concentration dependence of DNA unwinding by Srs2 $2^{\mathrm{C} \Delta 276}$ and find that a sub-stoichiometric amount of Rad51 is sufficient to inhibit the DNA unwinding activity (Figure S2). On the contrary, even a 4-fold excess of Rad51 (with respect to number of Rad51 binding sites) is not sufficient to block the DNA unwinding activity of Srs2 ${ }^{\mathrm{C}} 314$ (Figure S2). This experiment again shows that the interaction between Srs2 and Rad51 is mandatory for the inhibition of DNA unwinding.

\section{Multiple Srs2 molecules are required for DNA unwinding}

Srs2 exhibits a concentration threshold for helicase activity, with no detectable DNA unwinding observed at Srs2 concentrations below

Journal of Molecular Biology, Vol. 426, No. 9 (May 1, 2014): pg. 1883-1897. DOI. This article is (C) Elsevier and permission has been granted for this version to appear in e-Publications@Marquette. Elsevier does not grant permission for this article to be further copied/distributed or hosted elsewhere without the express permission from Elsevier. 
$50 \mathrm{nM}$ (Figures $1 \mathrm{~A} \& 1 \mathrm{D}$ ). This observation suggests that multiple Srs2 molecules might be required to interact with the DNA substrate before unwinding activity is observed. To test this hypothesis initially, we preequilibrated the DNA with a sub-threshold concentration (40 nM) of an enzymatically inactive form of Srs2, srs2-K41A, in which the conserved Lys in the ATP binding site has been mutated to Ala, ${ }^{5}$ followed by addition of increasing amounts of Srs $2^{\mathrm{C} \triangle 276}$. Pre-equilibration of the DNA with srs2-K41A completely blocks the DNA unwinding activity of Srs2 ${ }^{\mathrm{C} \Delta 276}$ that was added subsequently even when added in large molar excess (Figure 3A). This result shows that multiple active Srs2 molecules must be bound on the DNA in order to unwind.

To further examine the Rad51 mediated inhibition of Srs2 ${ }^{\mathrm{C} \Delta 276}$ catalyzed DNA unwinding, we pre-incubated the DNA substrate with 45 $\mathrm{nM}$ Rad51 and $40 \mathrm{nM}$ of the Srs $2^{\mathrm{C} \Delta 276}$ protein (that is inhibited by Rad51) (Figure 1B). Note that Rad51 does not stably bind to the short ssDNA segment in these experiments with a $t_{1 / 2}=0.1$ min (Figure $2 E$ ), and presumably should allow assembly of Srs2. When $40 \mathrm{nM}$ of Srs2 is present in the reaction we observe no DNA unwinding activity (Figure 1). We then added increasing concentrations of the Srs $2^{\mathrm{C} \Delta 314}$ protein to the reaction containing DNA and $40 \mathrm{nM} \mathrm{Srs} 2^{\mathrm{C} \Delta 276}$, and tested for DNA unwinding activity (Figure $3 \mathrm{~B}$ ). When the Srs2 ${ }^{\mathrm{C} \Delta 276}$-Rad51-DNA complex is challenged with the Srs $2^{\mathrm{C} \Delta 314}$ helicase no detectable unwinding activity is observed (Figure $3 \mathrm{~B}$ ) indicating the formation of a stable, inhibited complex of Srs2 and Rad51 bound to the DNA. Conversely, we observe DNA unwinding when we first pre-incubate the DNA with 40 nM Srs $2^{\mathrm{C} \Delta 314}$ (which does not interact with Rad51) followed by addition of increasing concentrations of Srs2 ${ }^{\mathrm{C}} 276$ (Figure $3 \mathrm{~B})$. These experiments suggest the existence of a high affinity DNA binding site for Srs2 that is required, but not sufficient for DNA unwinding. We conclude that occupancy of a high affinity site on the DNA by Srs2 is a prerequisite for helicase activity, and the interaction between Rad51 and the Srs 2 bound at this site creates a long-lived block of DNA unwinding.

To directly visualize whether multiple Srs2 molecules are bound on the DNA, we next examined DNA binding to Srs2 by monitoring the formation of Srs2-DNA complexes using electro mobility shift analysis (EMSA). Increasing amounts of $\operatorname{Srs} 2^{\mathrm{C} \Delta 276}$ were added to $5 \mathrm{nM}$ of the 
DNA (25 bp dsDNA with a 3' (dT)15 overhang) in the presence of the non-hydrolyzable ATP analog AMP-PNP to prevent unwinding activity (Figure 4). There are two complexes observed in the band shift experiment. The first complex migrating faster is observed across all Srs2 concentrations (labeled complex 1; Figure 4). An additional slower migrating band is observed only in lanes containing $75-250$ $\mathrm{nM}$ Srs2 in the reaction (labeled complex 2; Figure 4). A third much weaker complex is also observed closer to the well suggesting that at higher Srs2 concentrations more than two Srs2 molecules can bind to this DNA substrate. Similar results were also obtained for the shorter Srs ${ }^{\mathrm{C} \Delta 314}$ protein (data not shown). Occupancy of multiple UvrD molecules (the bacterial homolog of Srs2) has been observed on a similar DNA substrate. ${ }^{23 ; 24 ; 25}$ Multiple UvrD molecules have also been observed during DNA unwinding in single molecule analysis. ${ }^{26}$

\section{3' ssDNA overhang length dependence of DNA unwinding and ATP hydrolysis suggests oligomerization of Srs2 on DNA}

ATP hydrolysis fuels the DNA unwinding activity of Srs2. ${ }^{7}$ In addition to directly monitoring DNA unwinding, we analyzed ATP hydrolyzed by Srs2 during DNA unwinding (Figure 5A). A biphasic ATP hydrolysis profile is observed with little to no ATPase activity below 50 $\mathrm{nM}$ Srs2 in the reaction and a hyperbolic increase in ATPase activity at higher Srs2 concentrations (Figure 5A). These results mimic the results observed for the DNA unwinding activity (Figure $1 \mathrm{C}$ ). This lends additional support to our conclusion that multiple Srs2 molecules need to assemble on the DNA to initiate DNA unwinding. To test whether the assembly of the Srs 2 molecules occurs on the 3' ss tail of the DNA substrate, we performed the ATPase experiment on DNA substrates with increasing lengths of the 3' ssDNA overhang. The dsDNA was fixed at 25 bp and the length of the 3 ' ss tail was varied from 0 to 30 nt. A very sharp dependence of 3' ss tail length dependence of ATP hydrolysis is observed. Little to no ATPase activity is observed on substrates with tail lengths $0-10$ nt (Figure 5B). On longer tailed substrates (12-30 nt), ATPase activity is observed (Figure 5B). Similar results were obtained for the Srs $2^{\mathrm{C} \Delta 314}$ protein as well (data not shown).

Journal of Molecular Biology, Vol. 426, No. 9 (May 1, 2014): pg. 1883-1897. DOI. This article is (C) Elsevier and permission has been granted for this version to appear in e-Publications@Marquette. Elsevier does not grant permission for this article to be further copied/distributed or hosted elsewhere without the express permission from Elsevier. 
The $3^{\prime}$ ss tail length dependence is also observed in DNA unwinding experiments (Figure 5C). We analyzed the DNA unwinding activity of Srs2 ${ }^{\mathrm{C} \Delta 276}$ on DNA substrates with a 25 bp ds region and increasing lengths of the $3^{\prime}$ ss tail $(0-30 \mathrm{nt})$. Similar to the ATPase results (Figure $5 \mathrm{~B}$ ), there is no DNA unwinding activity on substrates with $3^{\prime}$ ss tail lengths less than 12 nt. However, robust unwinding is observed on longer $3^{\prime}$ ss tail substrates (Figure 5C). The crystal structure of SF-1 helicases such as UvrD, PcrA and Rep all show a minimum of 7 nt of $3^{\prime}$ ss tail occluded in the helicase core. ${ }^{27 ; 28 ; 29}$ Based on these structures, we suggest that one Srs2 molecule can bind to 7-10 nt of the 3' ss tail, but is not sufficient to unwind DNA. When the length of this tail is increased, more than one Srs2 molecule assembles leading to DNA unwinding activity.

In a previous study, using the full length version of Srs2 and longer DNA substrates (200 bp dsDNA with a 409 nt 3' ssDNA tail) Dupaigne et. al. showed that Rad51 is able to stimulate the DNA unwinding activity of Srs2. ${ }^{11}$ Since our findings are in contrast to their report, we repeated our DNA unwinding experiments on the longer DNA substrate and find that $S r s 2^{\mathrm{C} \Delta 276}$ is able to unwind this DNA just as efficiently as the shorter DNA unwinding substrates (Figure 6A). Moreover, when we incubated the long DNA substrate with Rad51, followed by addition of Srs $2^{\mathrm{C} \Delta 276}$, a time dependent inhibition of Srs2 unwinding was observed (Figure 6B). When we performed this experiment with the Srs $2^{\mathrm{C} \Delta 314}$ protein, we did not observe any DNA unwinding activity as this protein cannot remove the Rad51 filament from the long 409 nt ssDNA 3' tail (data not shown). The reason as to why we observe robust DNA unwinding with our Srs2 preparation versus their protein is not immediately obvious and as a consequence we have investigated the unwinding activity of the $\mathrm{Srs} 2^{\mathrm{FL}}$ protein as well (described below). One discrepancy between the two studies may be attributable to the poor solubility of the full length Srs2 protein and its tendency to aggregate in solution, which we encountered and reported in our earlier study. ${ }^{4}$ The truncated Srs2 protein alleviates this problem and is also able to unwind long DNA substrates, which appears not to be the case with the full length Srs2 protein. ${ }^{11}$

Journal of Molecular Biology, Vol. 426, No. 9 (May 1, 2014): pg. 1883-1897. DOI. This article is (C) Elsevier and permission has been granted for this version to appear in e-Publications@Marquette. Elsevier does not grant permission for this article to be further copied/distributed or hosted elsewhere without the express permission from Elsevier. 


\section{Rad51 inhibits the DNA unwinding activity of full length Srs2}

As mentioned above, our findings are in contrast to the observation that Rad51 stimulates the DNA unwinding activity of Srs2. ${ }^{11}$ Since a key difference between the studies are the versions of Srs2 used in the experiments, we performed our unwinding experiments with purified full length Srs2 protein ( $\mathrm{Srs} 2^{\mathrm{FL}}$ ). Srs2 ${ }^{\mathrm{FL}}$ tends to aggregate in solution and is sensitive to the buffer conditions for in vitro studies. Purifying the protein in buffer containing $20 \mathrm{mM}$ potassium phosphate ( $\mathrm{pH} 8.0$ ) and $20 \%$ glycerol alleviated some of the aggregation issues (data not shown) and we were able to observe DNA unwinding activity (Figure $7 \mathrm{~A}$ ). Srs $2^{\mathrm{FL}}$ unwinds DNA, but requires a $~ 2.5$-fold excess of protein to reach maximum DNA unwound (400 $\mathrm{nM}$ Srs2 $2^{\mathrm{FL}}$ for $60 \%$ unwinding; Figure $7 \mathrm{~A}$ ) compared to the truncated version ( $150 \mathrm{nM}$ Srs2 ${ }^{\mathrm{C} \Delta 276}$ for $60 \%$ unwinding; Figures $1 \mathrm{~A} \& 1 \mathrm{C}$ ). By titrating a broader range of Srs $2^{\mathrm{FL}}$ concentrations in the experiments, we were able to capture DNA unwinding and assess the effect of Rad51. Srs $2^{\mathrm{FL}}$ unwinds a 25 dsDNA substrate with a $3^{\prime}-15$ nt overhang (Figure 7A). Pre-incubation of the DNA substrate with Rad51 inhibits DNA unwinding when the unwinding reaction is incubated for 2 minutes (Figure 7B). As observed for Srs2 ${ }^{\mathrm{C} \Delta 276}$ truncation, allowing the unwinding reaction to proceed for 10 minutes removes the Rad51 dependent inhibition and unwinding is observed (Figures7D, E \& F). These results show that the Rad51 mediated inhibition of DNA unwinding by Srs 2 is observed for both the Srs $2^{\mathrm{FL}}$ (Figure $7 \mathrm{C}$ ) and the Srs $2^{\mathrm{C} \Delta 276}$ truncation and is lost only in the version of Srs2 lacking the ability to interact with Rad51 (Srs2 ${ }^{\mathrm{C} \Delta 314}$; Figure 1F).

\section{Rad51 retards the DNA unwinding of Srs2 6-fold in single-molecule experiments:}

Using single molecule FRET experiments, we recently showed that Rad51 inhibits the unwinding activity of the truncated Srs2 protein $\left(\operatorname{Srs} 2^{\mathrm{C} \Delta 276}\right) .30$ Since a $\sim 3$ fold excess of Srs2 $2^{\mathrm{FL}}$ protein is required to observe ample DNA unwinding in our bulk experiments (Figure 7A), we used single molecule FRET (smFRET) analysis to measure unwinding in the presence and absence of Rad51 (Figure 8). We used a Cy3-Cy5 FRET pair positioned at the DNA junction to monitor unwinding (Figure

Journal of Molecular Biology, Vol. 426, No. 9 (May 1, 2014): pg. 1883-1897. DOI. This article is @ Elsevier and permission has been granted for this version to appear in e-Publications@Marquette. Elsevier does not grant permission for this article to be further copied/distributed or hosted elsewhere without the express permission from Elsevier. 
8A). One strand is immobilized using biotin on the surface and the unwound strand dissociates leading to a drop in FRET signal (Figures $8 \mathrm{~A} \& 8 \mathrm{~B})$. The time window of the FRET signal $(\delta T)$ change from its highest point to its lowest point upon addition of Srs2 is quantified as the 'unwinding time' (Figure $8 \mathrm{C}$ ). Three examples of such unwinding times depicted as a drop in FRET signal are shown in Figure 8C. Similar unwinding times are measured in the presence of Rad51 by first pre-incubating the DNA substrate with Rad51 followed by the addition of Srs2 to the reaction (Figure 8D). The presence of Rad51 significantly elongates these unwinding times (Figure 8D). These unwinding times are measured for multiple single molecules and the average unwinding time is calculated as described. ${ }^{30}$ In the absence of Rad51, the average time to unwind the DNA for Srs $2^{\mathrm{FL}}$ versus Srs ${ }^{\mathrm{C} \Delta 276}$ was $16.8 \pm 0.98 \mathrm{~s}$ (Figure $8 \mathrm{E}$ ) and $5.98 \pm 0.04 \mathrm{~s}$ (Figure $8 \mathrm{G}$ ) respectively. Intrinsically, the unwinding rate of Srs $2^{\mathrm{FL}}$ is $\sim 3$ fold slower compared to the truncated Srs2 ${ }^{\mathrm{C} \Delta 276}$ protein and at the moment we do not clearly understand the basis for this difference. However, when Rad51 is pre-bound to the DNA, the average unwinding times are $108.49 \pm 3.41 \mathrm{~s}$ (Figure $8 \mathrm{~F}$ ) and $33.96 \pm 0.1 \mathrm{~s}$ (Figure $8 \mathrm{H}$ ) for the $\mathrm{Srs} 2^{\mathrm{FL}}$ and Srs2 ${ }^{\mathrm{C} \Delta 276}$ proteins respectively. Hence for the Srs $2^{\mathrm{FL}}$ protein, presence of Rad51 increases the average unwinding time by $\sim 6.5$ fold versus $\sim 5.7$ fold for the Srs $2^{\mathrm{C} \Delta 276}$ protein. Therefore the Rad51 dependent inhibition of the unwinding activity of Srs2 is not attributable to the differences between the Srs $2^{\mathrm{FL}}$ and the $\mathrm{Srs} 2^{\mathrm{C} \Delta 276}$ proteins. These results again support our model that Rad51 inhibits the DNA unwinding activity of Srs2. Rad51 dissociation from dsDNA allows Srs2 to proceed with DNA unwinding. This inhibition is observable only when Srs2 physically interacts with Rad51.

\section{Discussion}

The SF-1 helicase/translocase Srs2 interacts with the Rad51 recombinase in two different contexts, but with differing results. This interaction is required for Srs2 to disassemble a Rad51-ssDNA nucleoprotein filament, $4 ; 5 ; 20$ but inhibits dsDNA unwinding by Srs2 (Figures 1 and 2). Both of these Rad51-dependent activities are mediated through a protein-protein interaction with the C-terminal region of Srs2. The Srs $2^{\mathrm{C} \Delta 314}$ mutant lacking this $\mathrm{C}$-terminal segment fails to disassemble Rad51-ssDNA filaments, ${ }^{4}$ and its wild-type helicase

Journal of Molecular Biology, Vol. 426, No. 9 (May 1, 2014): pg. 1883-1897. DOI. This article is @ Elsevier and permission has been granted for this version to appear in e-Publications@Marquette. Elsevier does not grant permission for this article to be further copied/distributed or hosted elsewhere without the express permission from Elsevier. 
activity is not inhibited by Rad51 (Figures 1 and 2). Srs2 catalyzes Rad51 dissociation from ssDNA by stimulating Rad51 to hydrolyze ATP, in a filament clearing reaction that also requires the ATP-dependent translocation of Srs 2 along the ssDNA. ${ }^{4}$ On dsDNA, the interaction of Srs 2 with Rad51 prevents DNA unwinding by Srs2. In this context, a stable Srs2-DNA complex is formed that is resistant to challenge with high concentrations of $\mathrm{Srs} 2^{\mathrm{C} \Delta 314}$ (Figure 3B), a protein that is normally immune to inhibition by Rad51 (Figures 1 and 2). Whether the inhibition of DNA unwinding by Srs 2 is coupled to the ATPase activity of Rad51 remains to be explored.

Changes in the oligomeric nature of several SF-1 helicases is known to regulate their functions. ${ }^{31}$ While some SF-1 helicases have been shown to unwind DNA as monomers (Dda), ${ }^{32}$ others need to multimerize in order to display helicase activity. ${ }^{31 ; 33 ; 34 ; 35 ; 36}$ In the case of $E$. coli UvrD, 33;34;37;38 the monomeric enzymes are rapid and processive ssDNA translocases, but display minimal helicase activity and must form at least a dimer in order to activate helicase activity. ${ }^{26}$ This is also the case for the E. coli Rep helicase. In the case of Rep it has been shown that a subdomain (2B) is auto-inhibitory for Rep monomer helicase activity and dimerization relieves this inhibition. ${ }^{35 ; 36 ; 39}$ Although the current report has not examined the mechanism by which Srs2 unwinds duplex DNA, our results indicate that multiple Srs2 molecules are required to bind the DNA substrate in order to activate DNA unwinding activity. Qualitatively, we observe two concentration-dependent phases of Srs2 binding to the DNA substrate used for unwinding assays. The high affinity interaction of Srs2 with the DNA appears to have a pivotal role in both the helicase activity of Srs 2 as well as its inhibition by Rad51. Pre-incubation of the DNA with a subthreshold $40 \mathrm{nM}$ concentration of a catalytically inactive Srs2 mutant prevents subsequent DNA unwinding by an excess of catalytically active Srs2 protein (Figure 3). Occupancy of this high affinity DNA binding site(s) may interfere with DNA loading or translocation of the active helicase. The high affinity DNA site also participates in the Rad51-dependent inhibition of the Srs2 ${ }^{\mathrm{C} \Delta 276}$ helicase, and remarkably, pre-incubation with a low concentration of Srs2 ${ }^{\mathrm{C} \Delta 314}$ protects against Rad51 inhibition of DNA unwinding initiated by a high concentration of Srs $2^{\mathrm{C} \Delta 276}$ (Figure 3B). Pre-incubation with srs2-K41A causes a sustained block of DNA unwinding (Figure $3 \mathrm{~A}$ ),

Journal of Molecular Biology, Vol. 426, No. 9 (May 1, 2014): pg. 1883-1897. DOI. This article is @ Elsevier and permission has been granted for this version to appear in e-Publications@Marquette. Elsevier does not grant permission for this article to be further copied/distributed or hosted elsewhere without the express permission from Elsevier. 
and we infer that the Srs $2^{\mathrm{C} \Delta 314}$ protein also remains bound to the DNA and may function with $\mathrm{Srs} 2^{\mathrm{C} \triangle 276}$ in the DNA unwinding reaction (Figure $3 B$ ). Crystal structures of related SF-1 helicases UvrD ${ }^{27}$ and PcrA ${ }^{28}$ in complex with DNA show a binding site on ssDNA that spans approximately 7 nucleotides. By analogy, two molecules of Srs 2 could bind to the 15 nt ssDNA tail of the preferred substrate for DNA unwinding (Figure 5C).

The DNA unwinding activity of Srs2 may contribute to the down regulation of HR activity by dissociating branched DNA intermediates of recombination pathways. ${ }^{19}$ We have shown that the Rad51 recombinase in complex with dsDNA suppresses the helicase activity of Srs2 through a protein-protein interaction that, in another context, enables Srs2 to disassemble Rad51 filaments on ssDNA (Figure 9). ${ }^{4}$ This DNA context-sensitive regulation of Srs 2 by Rad51 would allow Srs2 to efficiently disassemble the Rad51-ssDNA filament without unwinding adjacent regions of dsDNA. Srs2 is subject to phosphorylation by the Cdk kinase at several residues along the Cterminal region. ${ }^{17 ; 40}$ One hypothesis would be that phosphorylation controls binding of Srs2 to Rad51 thereby regulating whether it functions to remove the Rad51 filament or unwind the DNA after Rad51 has been displaced. ${ }^{40 ; 41}$ Moreover, the unwinding activity can also be accomplished after Rad51 is displaced from the dsDNA by the Rad54 protein. Such a model could account for the lethality of the srs 2 rad54 strains which are suppressed by the loss of Rad51. ${ }^{42}$

Srs2 allosterically modulates ATP turnover by Rad $51,{ }^{4}$ and it will be of great interest to determine if there is a reciprocal effect on ATP hydrolysis by Srs 2 that is sensitive to the DNA binding context of the Rad51 recombinase. Moreover, the functional complex of Srs2-Rad51dsDNA might serve a signaling role, for example, to promote resolution of recombination intermediates into non-crossover products (Figure 9). Our findings have more general significance in demonstrating that the DNA remodeling activity of an ATP-dependent motor protein can be tailored by protein-protein interactions to produce different outcomes.

Journal of Molecular Biology, Vol. 426, No. 9 (May 1, 2014): pg. 1883-1897. DOI. This article is @ Elsevier and permission has been granted for this version to appear in e-Publications@Marquette. Elsevier does not grant permission for this article to be further copied/distributed or hosted elsewhere without the express permission from Elsevier. 
NOT THE PUBLISHED VERSION; this is the author's final, peer-reviewed manuscript. The published version may be accessed by following the link in the citation at the bottom of the page.

\section{Experimental Procedures}

Oligonucleotides: Unlabeled and fluorescein-isothiocyanate (FITC) labeled DNA oligonucleotides used for the DNA unwinding and binding experiments were synthesized on an ABI 394 DNA synthesizer or purchased from Integrated DNA Technologies (Coralville, IA) and gel purified before annealing. The dsDNA was formed by annealing a labeled top strand (EA-T:5'-CGATCGTCC-TCTAGACAGCTTACGC-3') and bottom strand (EA-B: 5'-GCGTAAGCTGTCTAGAGGAC$\operatorname{GATCG}[T](n)$, where $n=0-30 \mathrm{nt})$ to yield a 25 bp dsDNA with $3^{\prime}$ ssDNA overhangs of defined lengths ( $n$ ). For the single molecule FRET experiments, Cy5, or internally positioned aminomodifier-dT-labeled oligonucleotides were purchased from Integrated DNA Technologies (Coralville, IA). The following two oligonucleotides were used to form the 18 bp dsDNA substrate with a 17 nt $3^{\prime}$ overhang. pdT3+17: 5' (Cy5)-GCCTCGCTGCCGTCGCCA-(biotin)-3' + 5' TGGCGACGGCAGCGAGGC-(dT)3-(C6dT)-(dT) $17-3^{\prime}$. The $\mathrm{C} 6 \mathrm{dT}$ was labeled with $\mathrm{Cy} 3$ using a Cy3 monofunctional NHS ester (GE Healthcare, Princeton, NJ) as described. ${ }^{30}$

Proteins: Srs2 ${ }^{\mathrm{C} \Delta 276}$, Srs2 ${ }^{\mathrm{C} \triangle 314}$, Srs2 ${ }^{\mathrm{C} \triangle 276}-\mathrm{K} 41 \mathrm{~A}$, Rad51 and Rad51E221D proteins were overexpressed in $E$. coli and purified as described previously. ${ }^{4}$ To purify the full length Srs 2 protein, we generated a $9 \mathrm{X}$ His tagged version of Srs $2^{\mathrm{FL}}$ with an intervening Precission protease site to facilitate removal of the His tag. Srs $2^{\mathrm{FL}}$ protein was overexpressed similar to the truncated versions of Srs2 and the protocol for purification was modified as follows: The biomass was resuspended in Lysis Buffer (50 mM KHPO4, pH 8.0, 10 \% sucrose, 1 mM EDTA, 10 mM 2-mercaptoethanol, 1 M Urea, protease inhibitor cocktail and $0.5 \mathrm{M} \mathrm{NaCl})$ and lyzed using lysozyme $(0.3 \mathrm{mg} / \mathrm{ml})$ and sonication. Srs2 $2^{\mathrm{FL}}$ was precipitated from the clarified supernatant using $0.26 \mathrm{~g} / \mathrm{ml}$ ammonium sulfate. The subsequent pellet was resuspended in NTA Buffer (50 mM KHPO4, pH 8.0, $20 \%$ glycerol, 0.5 mM EDTA, 5 $\mathrm{mM} 2$-mercaptoethanol, protease inhibitor cocktail and $0.5 \mathrm{M} \mathrm{NaCl}$ ) and loaded onto a Ni2+-NTA column. After loading and removal of non-specific bound proteins, resin bound Srs 2 was subjected to overnight on-column proteolytic cleavage with 1:1000 ratio of Precission protease in Cleavage Buffer (50 mM KHPO4, pH 8.0, $20 \%$ glycerol, $5 \mathrm{mM}$ 2-mercaptoethanol, and $0.2 \mathrm{M} \mathrm{NaCl}$ ). Cleaved Srs2 was

Journal of Molecular Biology, Vol. 426, No. 9 (May 1, 2014): pg. 1883-1897. DOI. This article is @ Elsevier and permission has been granted for this version to appear in e-Publications@Marquette. Elsevier does not grant permission for this article to be further copied/distributed or hosted elsewhere without the express permission from Elsevier. 
collected and dialyzed into Heparin Buffer (50 mM KHPO4, pH 8.0, 20 \% glycerol, $0.5 \mathrm{mM}$ EDTA, $5 \mathrm{mM}$ 2-mercaptoethanol, and $0.3 \mathrm{M} \mathrm{NaCl}$ ) and further subjected to fractionation on a heparin column. Srs2 was loaded through line A on the FPLC and as 50\% B onto the heparin column with Heparin Buffer containing no $\mathrm{NaCl}$ in line $\mathrm{B}$. This ensured that Srs2 was in high salt buffer until just before entering the column. This key step prevented precipitation of Srs2. Srs2 was eluted with a linear gradient of $0.15-1 \mathrm{M} \mathrm{NaCl}$ and fractions containing Srs2 were pooled and very gently concentrated to a final concentration of $\sim 0.5$ $\mathrm{mg} / \mathrm{ml}$. Srs2 was dialyzed against storage buffer $(50 \mathrm{mM} \mathrm{KHPO4,} \mathrm{pH}$ 8.0, $20 \%$ glycerol, 0.5 mM EDTA, 10 mM 2-mercaptoethanol and 0.3 $\mathrm{M} \mathrm{NaCl}$ ) and small aliquots were flash frozen in liquid nitrogen and stored at $-80^{\circ} \mathrm{C}$.

DNA Unwinding Assays: DNA unwinding by Srs2 was measured by the monitoring the displacement of the labeled EA-T oligonucleotide prepared by labeling with $\mathrm{y}^{-32} \mathrm{P}-\mathrm{ATP}$ (Perkin Elmer) and polynucleotide kinase (NEB). Labeled DNA strands were annealed with a slight excess of an unlabeled complementary strand, and $5 \mathrm{nM}$ of the annealed DNA was incubated with increasing concentrations of Srs2 $2^{\mathrm{C} \Delta 276 / C \Delta 314}(0-0.25$ $\mu \mathrm{M})$ and ATP (2 mM) in DNA unwinding buffer (50 mM Tris- $\mathrm{Cl}, \mathrm{pH} 8.0$, $120 \mathrm{mM} \mathrm{NaCl}, 10 \mathrm{mM} \mathrm{MgCl} 2,100 \mu \mathrm{g} / \mathrm{ml} \mathrm{BSA}$ and $0.2 \mathrm{mM} \beta-$ mercaptoethanol) at $30{ }^{\circ} \mathrm{C}$ for the denoted amount of time before the reaction was quenched with stop buffer (100 mM EDTA, pH 8.0, $20 \%$ $\mathrm{v} / \mathrm{v}$ glycerol, and $0.4 \%$ SDS). For unwinding experiments with the Srs $2^{\mathrm{FL}}$ protein, $5 \mathrm{nM}$ of the labeled DNA was incubated with increasing concentrations of $\mathrm{Srs} 2^{\mathrm{FL}}(0-0.8 \mu \mathrm{M})$ in a modified DNA unwinding buffer $\left(20 \mathrm{mM} \mathrm{KHPO}_{4}, \mathrm{pH} 8.0,120 \mathrm{mM} \mathrm{NaCl}, 10 \mathrm{mM} \mathrm{MgCl}, 100 \mu \mathrm{g} / \mathrm{ml}\right.$ $\mathrm{BSA}$ and $0.2 \mathrm{mM} \beta$-mercaptoethanol) at $30{ }^{\circ} \mathrm{C}$ for the denoted time and quenched as above. The dsDNA substrate and dissociated ssDNA product strand were resolved by electrophoretic mobility shift analysis (EMSA) in a $10 \%$ TBE acrylamide gel (100 Volts at $25^{\circ} \mathrm{C}$ in $1 \mathrm{X}$ TBE), dried and quantified using a phosphor imager. For the sequentialincubation DNA unwinding experiments $5 \mathrm{nM}$ of ${ }^{32} \mathrm{P}$-labeled DNA was first incubated with $40 \mathrm{nM}$ of either Srs2-WT or Srs2-mutant at $30^{\circ} \mathrm{C}$ for 2 min in DNA unwinding buffer with $2 \mathrm{mM}$ ATP followed by addition of increasing concentrations of either Srs2-mutant or Srs2-WT (0-250 $\mathrm{nM})$, incubated for an additional 2 min before quenching and resolving the products as described above.

Journal of Molecular Biology, Vol. 426, No. 9 (May 1, 2014): pg. 1883-1897. DOI. This article is (C) Elsevier and permission has been granted for this version to appear in e-Publications@Marquette. Elsevier does not grant permission for this article to be further copied/distributed or hosted elsewhere without the express permission from Elsevier. 
To measure the effect of Rad51 on DNA unwinding by Srs2, FITC or ${ }^{32} \mathrm{P}$-labeled DNA was first incubated with 45 nM Rad51 in DNA unwinding buffer and $2 \mathrm{mM} \mathrm{ATP}$ at $30^{\circ} \mathrm{C}$ for 2 min followed by addition of increasing concentrations of $\operatorname{Srs}^{2 \mathrm{C} \Delta 276 / \mathrm{C} \Delta 314}(0-0.25 \mu \mathrm{M})$ or Srs2 ${ }^{\mathrm{FL}}(0-$ $0.8 \mu \mathrm{M})$. For the experiment where [Rad51] was varied, $0-0.25 \mu \mathrm{M}$ Rad51 (as noted) was first incubated with the DNA substrate at $30^{\circ} \mathrm{C}$ for 2 min followed by Srs 2 addition. Unwinding was monitored after 2 minutes of incubation, quenched, resolved and quantified as described above. The steady state rate of DNA unwinding was measured similarly in a $100 \mu \mathrm{l}$ reaction containing $5 \mathrm{nM}$ labeled DNA, $100 \mathrm{nM}$ Srs2 (in the presence or absence of $45 \mathrm{nM}$ Rad51) and $2 \mathrm{mM} \mathrm{ATP}$ at $30^{\circ} \mathrm{C}$. Reaction aliquots $(10 \mathrm{ul})$ were removed at the indicated times and quenched with $10 \mu$ of stop buffer, vortexed immediately, and stored on ice until the EMSA analysis was performed as described above. DNA unwinding by $\operatorname{Srs} 2^{\mathrm{C} \Delta 276}$ on the long DNA substrates were performed as described. ${ }^{11}$ Briefly, a 200 bp DNA substrate was generated with a 409 nt $3^{\prime}$ 'ssDNA overhang as described ${ }^{11}$ with a Cy5 label on the shorter strand. $\operatorname{Srs} 2^{\mathrm{C} \Delta 276}(0.5 \mu \mathrm{M})$ was incubated with 50 nM of labeled DNA for the indicated amount of time in the presence of $0.25 \mu \mathrm{M}$ RPA and in the presence or absence of $3 \mu \mathrm{M}$ Rad51. Reactions were quenched with an equal volume of quench buffer ( 25 mM EDTA, $1 \%$ SDS and $0.5 \mathrm{mg} / \mathrm{ml}$ proteinase $\mathrm{K})$ and analyzed using EMSA $(6.5 \%$ TBE acrylamide gel). The gel was scanned using a Typhoon Image set at the Cy5 wavelength.

DNA Binding EMSA Assay: The DNA binding activity of Srs2 was measured using a 32P-labeled DNA substrate (5 nM) with a $25 \mathrm{nt}$ dsDNA region and a 3' 15 nt ssDNA overhang. Binding was measured by incubating increasing concentrations of $\operatorname{Srs} 2^{C \Delta 76 / C \Delta 314}(0-0.25 \mu \mathrm{M})$ in DNA unwinding buffer in the presence of $2 \mathrm{mM} \mathrm{AMP-PNP}$ (to prevent Srs2 from unwinding the DNA). Reactions were incubated at $25^{\circ} \mathrm{C}$ for 10 minutes and the formation of the Srs2-DNA complexes were measured using EMSA on an $8 \%$ PAGE gel and resolved in $1 \mathrm{X}$ TBE buffer at $100 \mathrm{~V}$ at $25^{\circ} \mathrm{C}$.

Rad51 dissociation: Dissociation of Rad51 was measured by monitoring the release of free radiolabeled DNA from preformed Rad51 filaments using nitrocellulose filter binding technique. ${ }^{43}$ Rad51-DNA complexes were pre-formed using $0.2 \mu \mathrm{M}{ }^{32} \mathrm{P}$-labeled DNA, $1.8 \mu \mathrm{M}$ 
Rad51 and 5 mM ATP in DNA unwinding buffer $(100 \mu l$ reaction volume). The reaction was incubated at $25^{\circ} \mathrm{C}$ for 2 minutes to allow filament formation followed by addition of $100 \mu \mathrm{M}$ unlabeled $79 \mathrm{nt} \mathrm{dT}$ ssDNA oligonucleotide as a trap to capture the dissociating Rad51 molecules. At the depicted time points, $10 \mu \mathrm{l}$ of the reaction was removed and passed through a pre-equilibrated filter and washed with $150 \mu \mathrm{l}$ of the reaction buffer. The filters were dried and bound DNA was quantified using a phosphor imager. The data were fit to a single exponential equation $\left[X=A\left(1-\exp ^{(-k t)}\right)\right]$ to obtain the rate constant, $k$, for dissociation of rad51 from DNA, where $A$ is the amplitude.

ATPase Assays: ATP hydrolysis during DNA unwinding by Srs2 was measured by mixing increasing concentrations of Srs2 (0-0.25 $\mu \mathrm{M}$ ) with $5 \mathrm{nM}$ DNA and $2 \mathrm{mM} \alpha^{32} \mathrm{P}$-ATP (Perkin Elmer) for $2 \mathrm{~min}$ at $30^{\circ} \mathrm{C}$ in DNA unwinding buffer $(10 \mu$ reaction volume). The reaction was quenched by adding $10 \mu \mathrm{l}$ of $0.5 \mathrm{M}$ EDTA and ADP formation was monitored by spotting $1 \mu$ l of the reaction on a TLC plate, dried, and resolved with $0.6 \mathrm{M}$ phosphate buffer, $\mathrm{pH}$ 3.4. ADP formed was quantified using a phosphor imager.

smFRET Experiments: smFRET experiments were carried out in Rad51 reaction buffer containing $50 \mathrm{mM}$ Tris- $\mathrm{HCl}(\mathrm{pH} 7.5), 50 \mathrm{mM}$ $\mathrm{NaCl}, 10 \mathrm{mM} \mathrm{MgCl} 2$, with an oxygen scavenging system $(0.8 \% \mathrm{v} / \mathrm{v}$ dextrose, $1 \mathrm{mg} / \mathrm{ml}$ glucose oxidase, $0.03 \mathrm{mg} / \mathrm{ml}$ catalase, and $1 \% \mathrm{v} / \mathrm{v}$ 2-mercaptoethanol. All these reagents were purchased from Sigma Aldrich (St. Louis, MO). The measurements were performed at room temperature $\left(21^{\circ} \mathrm{C} \pm 1^{\circ} \mathrm{C}\right)$ and $1 \mathrm{mM}$ ATP was used in all the experiments unless otherwise specified. $1 \mu \mathrm{M}$ Rad51 was mixed with Rad51 reaction buffer and ATP and added to the immobilized DNA as described previously. ${ }^{30} \mathrm{Srs} 2(200 \mathrm{nM})$ was mixed with Rad51 reaction buffer and ATP and added to a flow chamber that had 100 pM DNA specifically immobilized on a PEG-coated quartz surface through biotinneutravidin linkage. smFRET measurements were made using a widefield total internal reflection fluorescence microscope. Cy3 (donor) on DNA was excited by an Nd:YAG laser (532nM, 75mW, Coherent CUBE) via total internal reflection. The fluorescence signals from $\mathrm{Cy} 3$ and Cy5 were collected through an objective (Olympus Uplan S-Apo; X100 numerical aperture; 1.4 oil immersion) and detected at $100 \mathrm{~ms}$ time 
resolution using an EMCCD (electron multiplying charge-coupled device) camera (iXon DU-897ECS0-\#BV; Andor Technology). The camera was controlled using a custom $\mathrm{C}++$ program. Single-molecule traces were extracted from the recorded video file by IDL software (Exelis VIS, Boulder, CO).

\section{Acknowledgements}

We thank Dr. Tom Ellenberger and Dr. Tim Lohman (Washington University School of Medicine in St. Louis, MO) for supporting preliminary data collection in their laboratories. We also thank Dr. Peter Burgers (Washington University School of Medicine in St. Louis, MO) for providing us with yeast RPA protein. This work was supported through start-up funds from Utah State University to EA and a Research Scholar Grant from the American Cancer Society to SM (RSG-12-066-01-DMC). JV was supported by an URCO (undergraduate research and creative opportunities) grant from Utah State University.

\section{REFERENCES}

1. Sung, P. \& Klein, H. (2006). Mechanism of homologous recombination: mediators and helicases take on regulatory functions. Nat Rev Mol Cell Biol 7, 739-50.

2. Sung, P., Trujillo, K. M. \& Van Komen, S. (2000). Recombination factors of Saccharomyces cerevisiae. Mutat Res 451, 257-75.

3. Macris, M. A. \& Sung, P. (2005). Multifaceted role of the Saccharomyces cerevisiae Srs2 helicase in homologous recombination regulation. Biochem Soc Trans 33, 1447-50.

4. Antony, E., Tomko, E. J., Xiao, Q., Krejci, L., Lohman, T. M. \& Ellenberger, T. (2009). Srs2 disassembles Rad51 filaments by a protein-protein interaction triggering ATP turnover and dissociation of Rad51 from DNA. Mol Cell 35, 105-15.

5. Krejci, L., Van Komen, S., Li, Y., Villemain, J., Reddy, M. S., Klein, H., Ellenberger, T. \& Sung, P. (2003). DNA helicase Srs2 disrupts the Rad51 presynaptic filament. Nature 423, 305-9.

6. Colavito, S., Macris-Kiss, M., Seong, C., Gleeson, O., Greene, E. C., Klein, H. L., Krejci, L. \& Sung, P. (2009). Functional significance of the Rad51-Srs2 complex in Rad51 presynaptic filament disruption. Nucleic Acids Res.

Journal of Molecular Biology, Vol. 426, No. 9 (May 1, 2014): pg. 1883-1897. DOI. This article is @ Elsevier and permission has been granted for this version to appear in e-Publications@Marquette. Elsevier does not grant permission for this article to be further copied/distributed or hosted elsewhere without the express permission from Elsevier. 
7. Van Komen, S., Reddy, M. S., Krejci, L., Klein, H. \& Sung, P. (2003). ATPase and DNA helicase activities of the Saccharomyces cerevisiae anti-recombinase Srs2. J Biol Chem 278, 44331-7.

8. Fabre, F., Chan, A., Heyer, W. D. \& Gangloff, S. (2002). Alternate pathways involving Sgs1/Top3, Mus81/ Mms4, and Srs2 prevent formation of toxic recombination intermediates from single-stranded gaps created by DNA replication. Proc Natl Acad Sci U S A 99, 1688792.

9. Gangloff, S., Soustelle, C. \& Fabre, F. (2000). Homologous recombination is responsible for cell death in the absence of the Sgs1 and Srs2 helicases. Nat Genet 25, 192-4.

10. Le Breton, C., Dupaigne, P., Robert, T., Le Cam, E., Gangloff, S., Fabre, F. $\&$ Veaute, X. (2008). Srs2 removes deadly recombination intermediates independently of its interaction with SUMO-modified PCNA. Nucleic Acids Res 36, 4964-74.

11. Dupaigne, P., Le Breton, C., Fabre, F., Gangloff, S., Le Cam, E. \& Veaute, X. (2008). The Srs2 helicase activity is stimulated by Rad51 filaments on dsDNA: implications for crossover incidence during mitotic recombination. Mol Cell 29, 243-54.

12. Robert, T., Dervins, D., Fabre, F. \& Gangloff, S. (2006). Mrc1 and Srs2 are major actors in the regulation of spontaneous crossover. Embo $\mathrm{J}$ 25, 2837-46.

13. Dhar, A. \& Lahue, R. S. (2008). Rapid unwinding of triplet repeat hairpins by Srs2 helicase of Saccharomyces cerevisiae. Nucleic Acids Res 36, 3366-73.

14. Bhattacharyya, S. \& Lahue, R. S. (2005). Srs2 helicase of Saccharomyces cerevisiae selectively unwinds triplet repeat DNA. J Biol Chem 280, 33311-7.

15. Bhattacharyya, S. \& Lahue, R. S. (2004). Saccharomyces cerevisiae Srs2 DNA helicase selectively blocks expansions of trinucleotide repeats. Mol Cell Biol 24, 7324-30.

16. Daee, D. L., Mertz, T. \& Lahue, R. S. (2007). Postreplication repair inhibits CAG.CTG repeat expansions in Saccharomyces cerevisiae. Mol Cell Biol 27, 102-10.

17. Chiolo, I., Carotenuto, W., Maffioletti, G., Petrini, J. H., Foiani, M. \& Liberi, G. (2005). Srs2 and Sgs1 DNA helicases associate with Mre11 in different subcomplexes following checkpoint activation and CDK1mediated Srs2 phosphorylation. Mol Cell Biol 25, 5738-51.

18. Liberi, G., Chiolo, I., Pellicioli, A., Lopes, M., Plevani, P., Muzi-Falconi, M. \& Foiani, M. (2000). Srs2 DNA helicase is involved in checkpoint response and its regulation requires a functional Mec1-dependent pathway and Cdk1 activity. EMBO J 19, 5027-38.

Journal of Molecular Biology, Vol. 426, No. 9 (May 1, 2014): pg. 1883-1897. DOI. This article is @ Elsevier and permission has been granted for this version to appear in e-Publications@Marquette. Elsevier does not grant permission for this article to be further copied/distributed or hosted elsewhere without the express permission from Elsevier. 
19. Ira, G., Malkova, A., Liberi, G., Foiani, M. \& Haber, J. E. (2003). Srs2 and Sgs1-Top3 suppress crossovers during double-strand break repair in yeast. Cell 115, 401-11.

20. Veaute, X., Jeusset, J., Soustelle, C., Kowalczykowski, S. C., Le Cam, E. \& Fabre, F. (2003). The Srs2 helicase prevents recombination by disrupting Rad51 nucleoprotein filaments. Nature 423, 309-12.

21. Hilario, J., Amitani, I., Baskin, R. J. \& Kowalczykowski, S. C. (2009). Direct imaging of human Rad51 nucleoprotein dynamics on individual DNA molecules. Proc Natl Acad Sci U S A 106, 361-8.

22. Colavito, S., Macris-Kiss, M., Seong, C., Gleeson, O., Greene, E. C., Klein, H. L., Krejci, L. \& Sung, P. (2009). Functional significance of the Rad51-Srs2 complex in Rad51 presynaptic filament disruption. Nucleic Acids Res 37, 6754-64.

23. Ali, J. A., Maluf, N. K. \& Lohman, T. M. (1999). An oligomeric form of E. coli UvrD is required for optimal helicase activity. J Mol Biol 293, 81534.

24. Maluf, N. K., Fischer, C. J. \& Lohman, T. M. (2003). A Dimer of Escherichia coli UvrD is the active form of the helicase in vitro. $\mathrm{J} \mathrm{Mol}$ Biol 325, 913-35.

25. Maluf, N. K. \& Lohman, T. M. (2003). Self-association equilibria of Escherichia coli UvrD helicase studied by analytical ultracentrifugation. J Mol Biol 325, 889-912.

26. Lee, K. S., Balci, H., Jia, H., Lohman, T. M. \& Ha, T. (2013). Direct imaging of single UvrD helicase dynamics on long single-stranded DNA. Nat Commun 4, 1878.

27. Lee, J. Y. \& Yang, W. (2006). UvrD helicase unwinds DNA one base pair at a time by a two-part power stroke. Cell 127, 1349-60.

28. Velankar, S. S., Soultanas, P., Dillingham, M. S., Subramanya, H. S. \& Wigley, D. B. (1999). Crystal structures of complexes of PcrA DNA helicase with a DNA substrate indicate an inchworm mechanism. Cell 97, 75-84.

29. Korolev, S., Hsieh, J., Gauss, G. H., Lohman, T. M. \& Waksman, G. (1997). Major domain swiveling revealed by the crystal structures of complexes of E. coli Rep helicase bound to single-stranded DNA and ADP. Cell 90, 635-47.

30. Qiu, Y., Antony, E., Doganay, S., Koh, H. R., Lohman, T. M. \& Myong, S. (2013). Srs2 prevents Rad51 filament formation by repetitive motion on DNA. Nat Commun 4, 2281.

31. Lohman, T. M., Tomko, E. J. \& Wu, C. G. (2008). Non-hexameric DNA helicases and translocases: mechanisms and regulation. Nat Rev Mol Cell Biol 9, 391-401.

Journal of Molecular Biology, Vol. 426, No. 9 (May 1, 2014): pg. 1883-1897. DOI. This article is @ Elsevier and permission has been granted for this version to appear in e-Publications@Marquette. Elsevier does not grant permission for this article to be further copied/distributed or hosted elsewhere without the express permission from Elsevier. 
32. Eoff, R. L. \& Raney, K. D. (2006). Intermediates revealed in the kinetic mechanism for DNA unwinding by a monomeric helicase. Nat Struct Mol Biol 13, 242-9.

33. Lucius, A. L., Maluf, N. K., Fischer, C. J. \& Lohman, T. M. (2003). General methods for analysis of sequential "n-step" kinetic mechanisms: application to single turnover kinetics of helicase-catalyzed DNA unwinding. Biophys J 85, 2224-39.

34. Niedziela-Majka, A., Chesnik, M. A., Tomko, E. J. \& Lohman, T. M. (2007). Bacillus stearothermophilus PcrA Monomer Is a Single-stranded DNA Translocase but Not a Processive Helicase in Vitro. J Biol Chem 282, 27076-85.

35. Cheng, W., Hsieh, J., Brendza, K. M. \& Lohman, T. M. (2001). E. coli Rep oligomers are required to initiate DNA unwinding in vitro. $\mathrm{J} \mathrm{Mol} \mathrm{Biol}$ 310, 327-50.

Brendza, K. M., Cheng, W., Fischer, C. J., Chesnik, M. A., Niedziela-Majka, A. \& Lohman, T. M. (2005). Autoinhibition of Escherichia coli Rep monomer helicase activity by its 2B subdomain. Proc Natl Acad Sci U S A 102, 10076-81.

37. Tomko, E. J., Fischer, C. J., Niedziela-Majka, A. \& Lohman, T. M. (2007). A nonuniform stepping mechanism for E. coli UvrD monomer translocation along single-stranded DNA. Mol Cell 26, 335-47.

38. Fischer, C. J., Maluf, N. K. \& Lohman, T. M. (2004). Mechanism of ATPdependent translocation of E.coli UvrD monomers along singlestranded DNA. J Mol Biol 344, 1287-309.

39. Cheng, W., Brendza, K. M., Gauss, G. H., Korolev, S., Waksman, G. \& Lohman, T. M. (2002). The 2B domain of the Escherichia coli Rep protein is not required for DNA helicase activity. Proc Natl Acad Sci U S A 99, 16006-11.

40. Saponaro, M., Callahan, D., Zheng, X., Krejci, L., Haber, J. E., Klein, H. L. \& Liberi, G. (2010). Cdk1 targets Srs2 to complete synthesisdependent strand annealing and to promote recombinational repair. PLoS Genet 6, e1000858.

41. Vaze, M. B., Pellicioli, A., Lee, S. E., Ira, G., Liberi, G., Arbel-Eden, A., Foiani, M. \& Haber, J. E. (2002). Recovery from checkpoint-mediated arrest after repair of a doublestrand break requires Srs2 helicase. Mol Cell 10, 373-85.

42. Signon, L., Malkova, A., Naylor, M. L., Klein, H. \& Haber, J. E. (2001). Genetic requirements for RAD51- and RAD54-independent breakinduced replication repair of a chromosomal double-strand break. Mol Cell Biol 21, 2048-56.

43. Antony, E. \& Hingorani, M. M. (2004). Asymmetric ATP binding and hydrolysis activity of the Thermus aquaticus MutS dimer is key to

Journal of Molecular Biology, Vol. 426, No. 9 (May 1, 2014): pg. 1883-1897. DOI. This article is @ Elsevier and permission has been granted for this version to appear in e-Publications@Marquette. Elsevier does not grant permission for this article to be further copied/distributed or hosted elsewhere without the express permission from Elsevier. 
NOT THE PUBLISHED VERSION; this is the author's final, peer-reviewed manuscript. The published version may be accessed by following the link in the citation at the bottom of the page.

modulation of its interactions with mismatched DNA. Biochemistry 43, 13115-28.

\section{FIGURE LEGENDS}

\section{Figure 1}

A
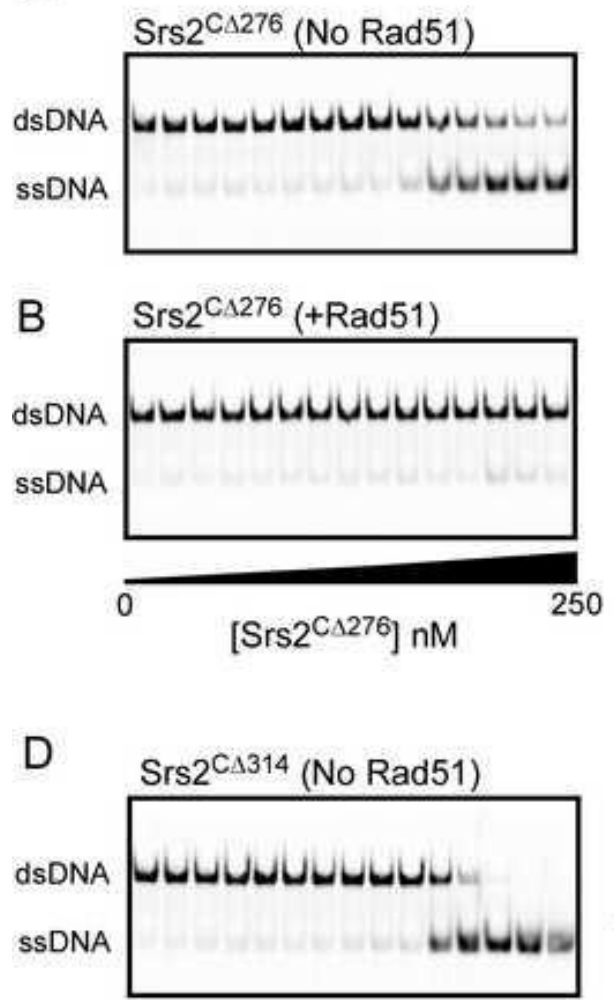

E $\quad \operatorname{Srs}^{\mathrm{C} A 314}(+\operatorname{Rad} 51)$

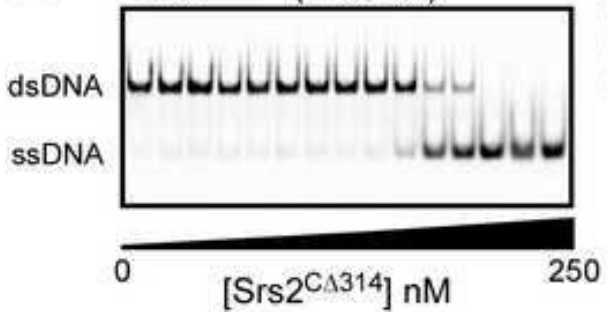

C

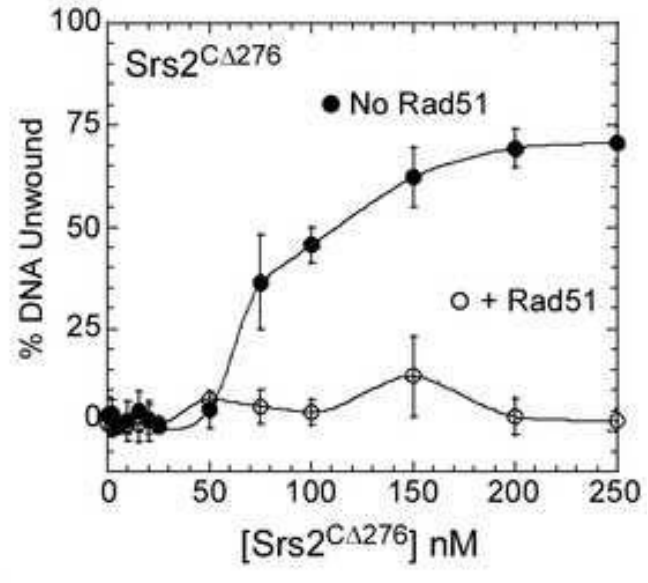

$\mathrm{F}$

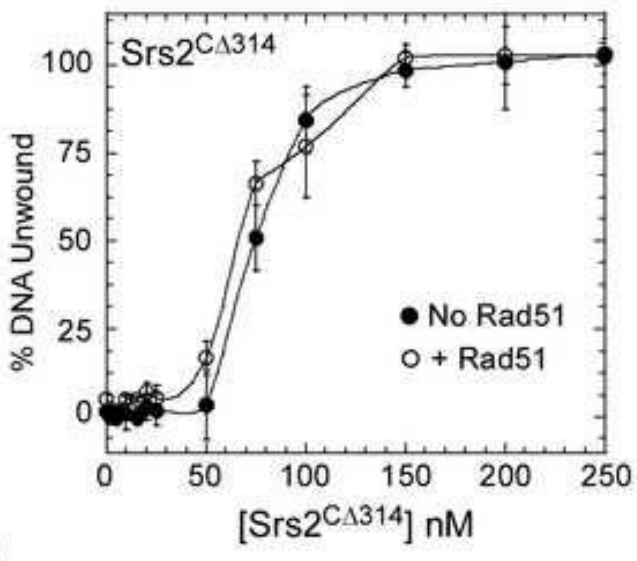

FIGURE 1. Rad51 inhibits DNA unwinding by Srs2. (A) DNA unwinding activity of the $\operatorname{Srs} 2^{\mathrm{C} \Delta 276}$ protein (B) is inhibited by $45 \mathrm{nM}$ Rad51. Increasing concentrations of Srs2 ${ }^{\mathrm{C} \Delta 276}$ was mixed with the DNA substrate ( 25 bp dsDNA with $3^{\prime} 15$ nt ssDNA overhang) then incubated for 2 minutes before analyzing product formation. (C) Plotting the percent DNA unwound in (A \& B) as a function of Srs 2 concentration shows a threshold for DNA unwinding at about $50 \mathrm{nM} \mathrm{Srs2,} \mathrm{and} \mathrm{marked} \mathrm{inhibition} \mathrm{of}$ helicase activity by Rad51. (D) An analysis of DNA unwinding by the truncated Srs2 ${ }^{\mathrm{C} \triangle 314}$ protein and (E) shows it is resistant to inhibition by Rad51. (F) A plot of the 
NOT THE PUBLISHED VERSION; this is the author's final, peer-reviewed manuscript. The published version may be accessed by following the link in the citation at the bottom of the page.

results from panel ( $D$ \& E) shows that Rad51 does not inhibit the DNA unwinding activity of Srs2 ${ }^{\mathrm{C} \Delta 314}$. The Srs2 ${ }^{\mathrm{C} \Delta 314}$ construct lacks the Rad51 interaction domain. The experiments were carried out for 2 minutes.

Figure 2

\section{A}

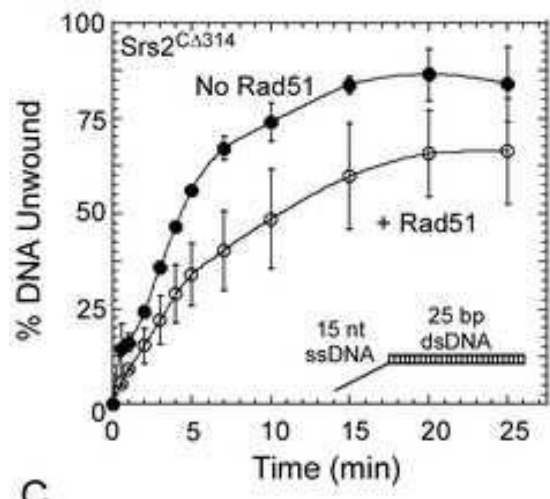

C

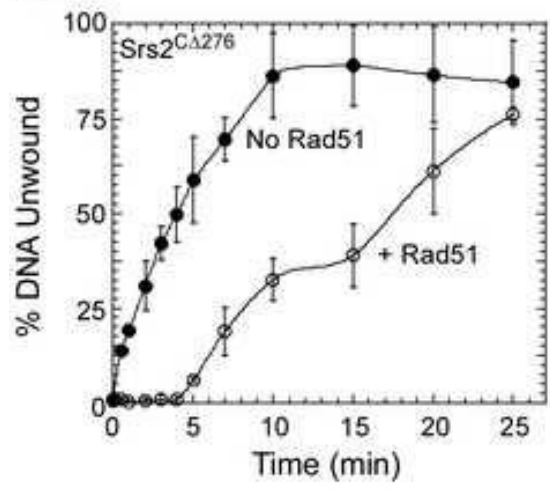

E

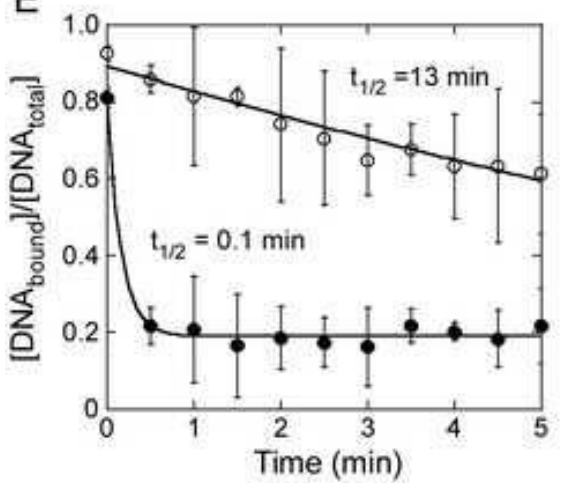

B

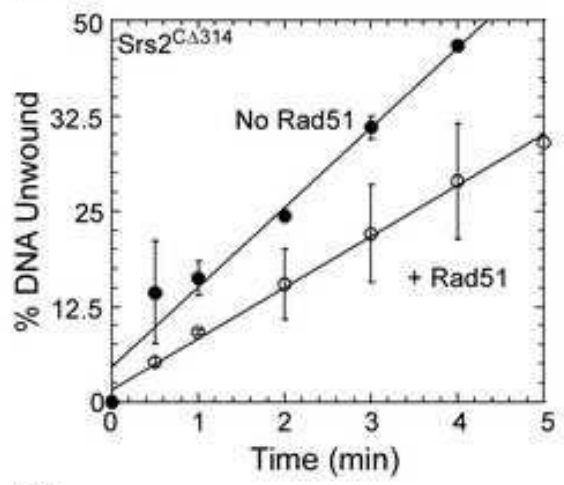

D

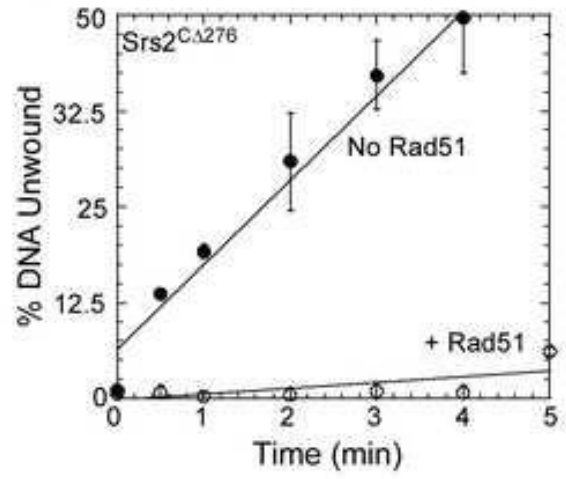

F

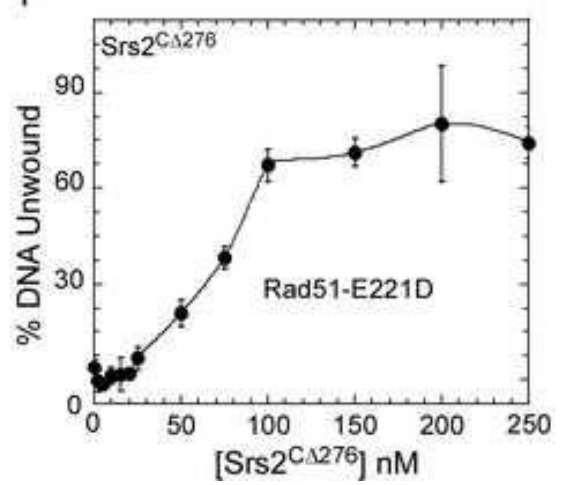

FIGURE 2. Rad51 physically blocks DNA unwinding by Srs2. (A) A longer time course of the DNA unwinding catalyzed by $200 \mathrm{nM} \mathrm{Srs2}{ }^{\mathrm{C}} 314$, which does not physically interact with Rad514, reveals modest inhibition by Rad51. (B) The initial part of the data (up to 6 minutes) fit to a linear equation. The initial rates of DNA unwinding are $0.041 \pm 0.005 \mathrm{~min}^{-1}$ and $0.027 \pm 0.008 \mathrm{~min}-1$ in the absence and presence of Rad51, respectively. (C) The DNA unwinding activity if Srs2 ${ }^{C} \triangle 276$ is strongly inhibited by Rad51 at early time points, followed by a substantial increase in helicase activity later in the 
reaction. The initial rates of DNA unwinding are $0.043 \pm 0.004 \mathrm{~min}^{-1}$ and $0.002 \pm$ $0.001 \mathrm{~min}^{-1}$ in the absence and presence of Rad51, respectively. (E) Rad51 dissociation from DNA was measured by a filter binding assay. Rad51 dissociates quickly $\left(\mathrm{t}_{1 / 2} \approx 0.1 \mathrm{~min}\right)$ from a $15 \mathrm{nt}$ ssDNA corresponding to the unpaired tail of the DNA substrate for unwinding. The half-life on the tailed duplex DNA substrate for the helicase assays is $t_{1 / 2} \approx 13 \mathrm{~min}$ ). (F) The rad51(E221D) mutant binds weakly to dsDNA (Fig. S1) and fails to inhibit the DNA unwinding activity of the Srs2 ${ }^{\mathrm{C} \triangle 276}$ helicase.

\section{Figure 3}
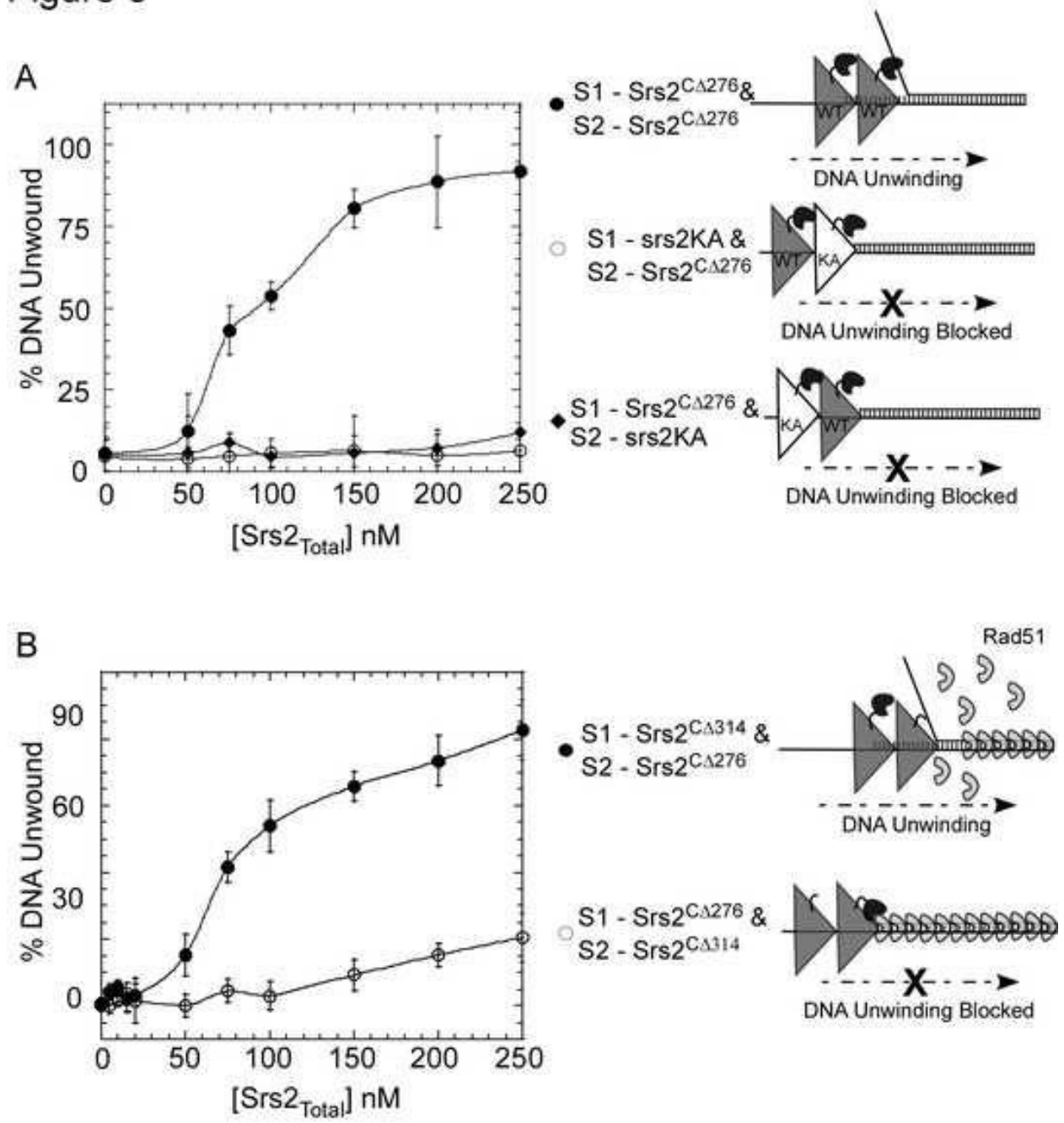

FIGURE 3. Rad51 inhibits DNA unwinding of Srs2 through a direct physical interaction. (A) The DNA substrate for unwinding was pre-incubated with a low concentration $(40 \mathrm{nM})$ of Srs2 protein that is insufficient to catalyze DNA unwinding, followed by addition of higher concentrations Srs2 proteins and measurement of the helicase activity after a 2 min. incubation. (A) Pre-incubation with $40 \mathrm{nM}$ catalytically inactive $\mathrm{srs}_{(\mathrm{K} 41 \mathrm{~A})}$ blocks subsequent DNA unwinding activity by $\mathrm{Srs}^{\mathrm{C} \triangle 276}(0)$ in comparison to a control reaction that was pre-incubated with $40 \mathrm{nM}$ Srs2 ${ }^{\mathrm{C}} \Delta 276$ before addition of more $\operatorname{Srs}^{\mathrm{C} \Delta 276}(\bullet)$. (B) In the presence of Rad51 (45 nM), pre-incubation of DNA with Srs2 $2^{\mathrm{C} \Delta 276}$ substantially inhibits helicase activity of Srs2 $2^{\mathrm{C} \Delta 314}$ even when added in vast molar excess ( $\circ$ ). On the contrary, pre-incubation with Srs2 ${ }^{\mathrm{C} \Delta 314}$, which 
NOT THE PUBLISHED VERSION; this is the author's final, peer-reviewed manuscript. The published version may be accessed by following the link in the citation at the bottom of the page.

does not physically interact with Rad51, ${ }^{4}$ preserves the helicase activity of $\operatorname{Srs} 2^{\mathrm{C} \Delta 276}$ in the presence of Rad51 $(\bullet)$.

\section{Figure 4}

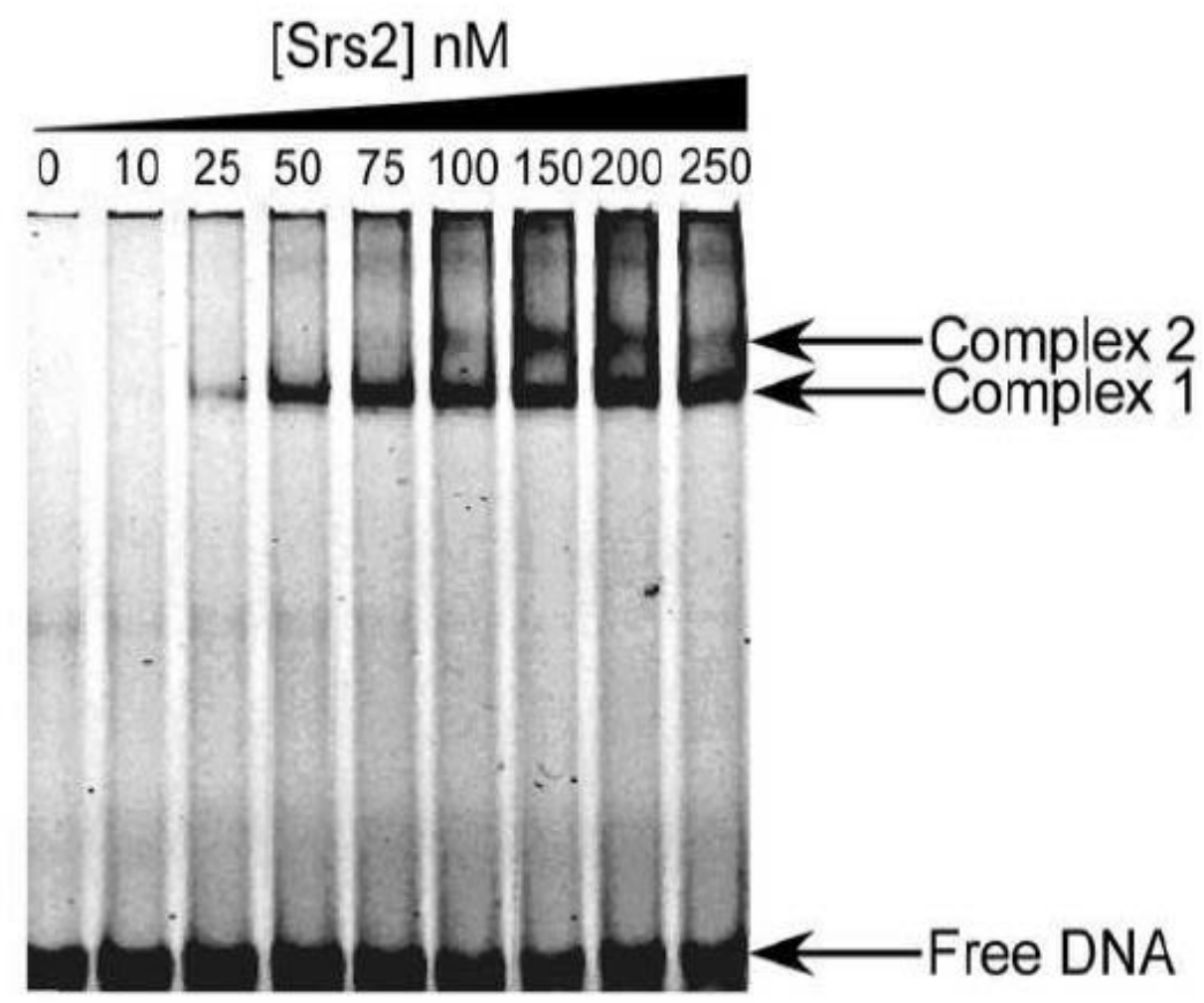

FIGURE 4. Multiple Srs2 molecules bind to DNA during the unwinding reaction. An EMSA experiment showing formation of Srs2CA276-DNA complexes. Increasing concentrations of Srs2 ${ }^{\mathrm{C} \triangle 276}$ were incubated with DNA (25 bp dsDNA with a $3^{\prime} 15 \mathrm{nt}$ overhang). A slower migrating band is observed in the presence of 10 to 250 $\mathrm{nM}$ protein (Complex 1). A second slower migrating band is observed only at Srs2 concentrations $75 \mathrm{nM}$ or higher (Complex 2). The non-hydrolyzable ATP analog AMPPNP ( $2 \mathrm{mM}$ ) was included to prevent DNA unwinding by Srs2. 
NOT THE PUBLISHED VERSION; this is the author's final, peer-reviewed manuscript. The published version may be accessed by following the link in the citation at the bottom of the page.

\section{Figure 5}
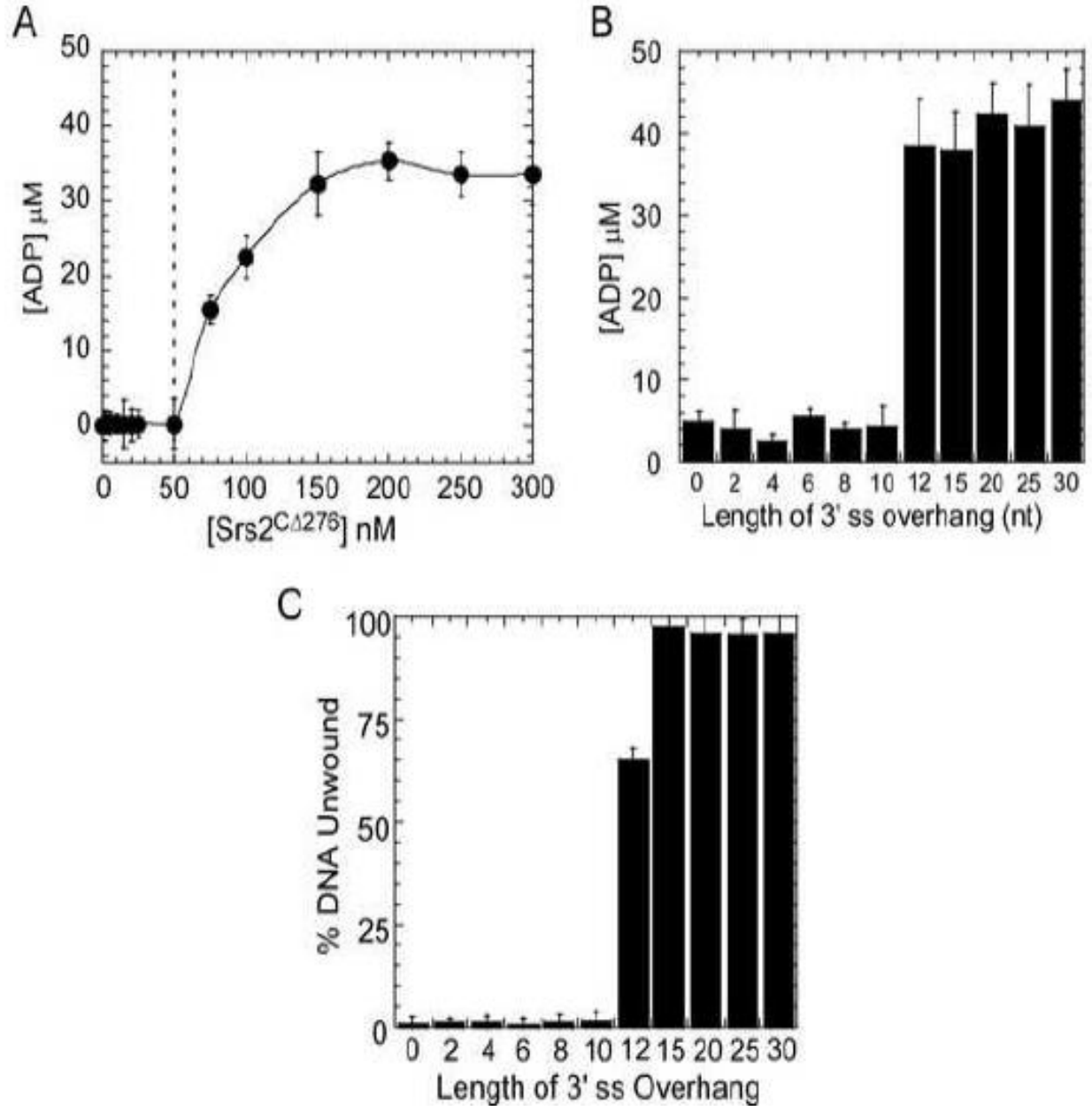

FIGURE 5. 3'sSDNA tail dependence of Srs2 ATPase and DNA unwinding activity (A) The extent of ATP hydrolysis during DNA unwinding by Srs2 recapitulates the biphasic behavior observed for DNA unwinding with a similar concentration threshold of $50 \mathrm{nM}$ Srs2 (dotted line). (B) Stimulation of ATP hydrolysis by Srs2 is observed only on DNA substrates with $3^{\prime}$ ssDNA overhangs of 12 or more nts. (C) The 3' ssDNA length dependence of Srs2 DNA unwinding activity shows that a minimum of $12 \mathrm{nt}$ is required to observe DNA unwinding, possibly corresponding to multiple Srs2 molecules binding to the DNA. 
NOT THE PUBLISHED VERSION; this is the author's final, peer-reviewed manuscript. The published version may be accessed by following the link in the citation at the bottom of the page.

Figure 6

A No Rad5
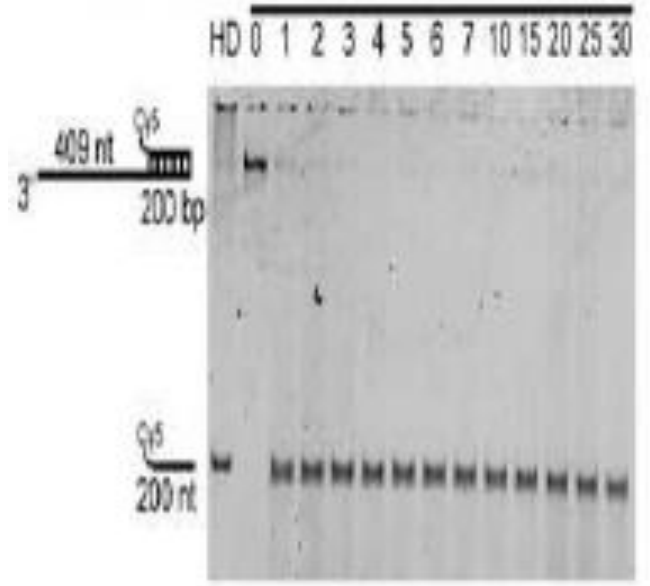

B $\quad$ Rad51

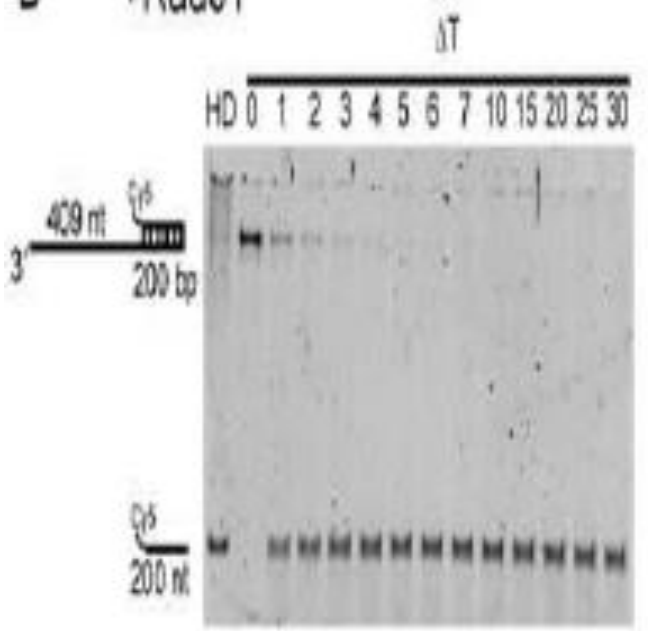

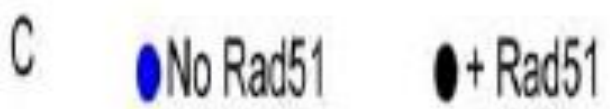

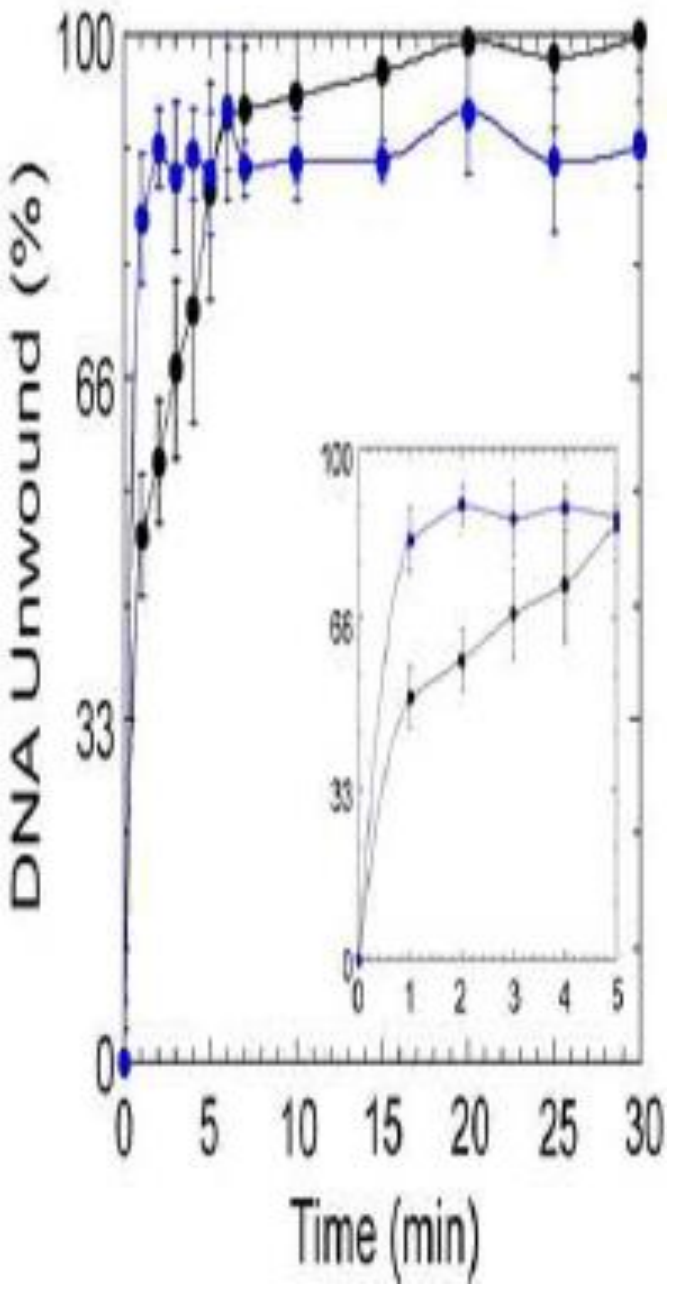

FIGURE 6. DNA unwinding activity of Srs2 ${ }^{\mathrm{c} \triangle 276}$ on long DNA substrates. $(A)$ DNA unwinding activity of Srs2 ${ }^{\mathrm{C}} \Delta 276$ was monitored on a 200 bp dsDNA substrate with a 409 nt 3'ssDNA overhang. The short 200 bp annealed strand had a Cy5 probe which was used to observe the unwound strand in EMSA. (A) Srs2 ${ }^{\mathrm{C} \Delta 276}$ unwinds DNA rapidly in the absence of Rad51. (B) When the DNA is incubated with Rad51, it retards the DNA unwinding activity of Srs2 $2^{\mathrm{C} \triangle 276}$. (C) Quantification of the percent DNA unwound as a function of time and shows that the unwinding activity is slowed down when Rad51 is bound to the DNA substrate. 
NOT THE PUBLISHED VERSION; this is the author's final, peer-reviewed manuscript. The published version may be accessed by following the link in the citation at the bottom of the page.

Figure 7

$\begin{array}{llll}\text { A } & 0 & {\left[\mathrm{Srs} 2^{\mathrm{FL}}\right] \mu \mathrm{M}} & 0.75\end{array}$

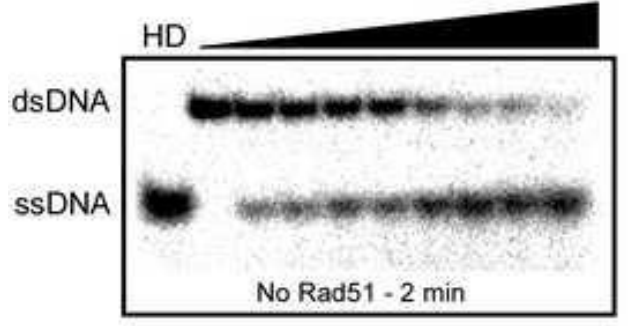

$\begin{array}{llll}\text { B } & 0 & {\left[\mathrm{SrS}^{\mathrm{FL}}\right] \mu \mathrm{M}} & 0.75\end{array}$
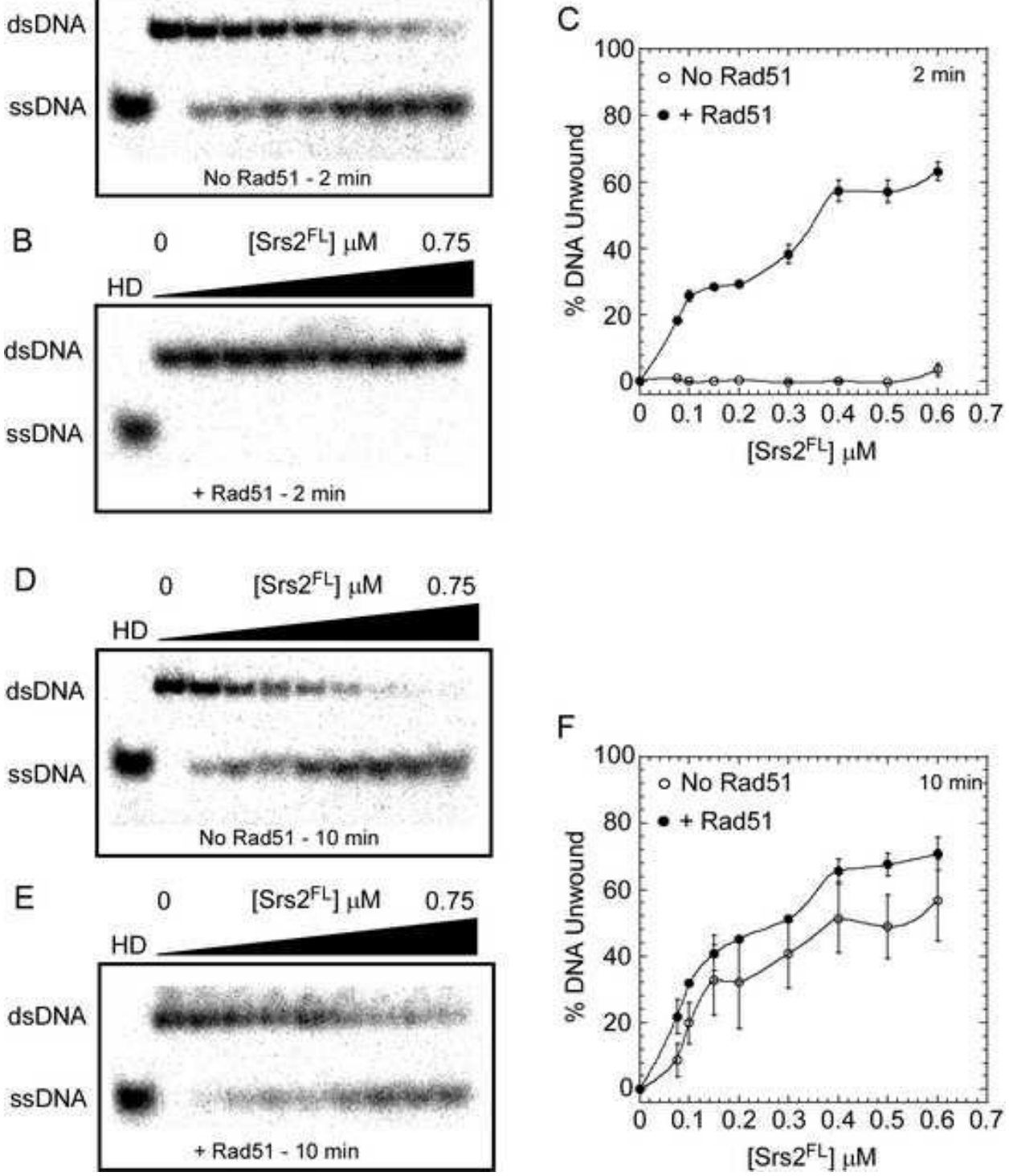

FIGURE 7. Rad51 inhibits the DNA unwinding activity of full length Srs2. DNA unwinding by Srs2 was measured for 2 minutes in (A) the absence or (B) presence of Rad51. (C) Shows quantification of results from $A$ and $B$ and shows that Rad51 inhibits DNA unwinding over a 2 minute period. Similar experiments performed over 10 minutes in (D) the absence or (E) presence of Rad51 and (F) their respective quantification show that the inhibition of DNA unwinding by Rad51 is significantly reduced. 
NOT THE PUBLISHED VERSION; this is the author's final, peer-reviewed manuscript. The published version may be accessed by following the link in the citation at the bottom of the page.

\section{Figure 8}

A

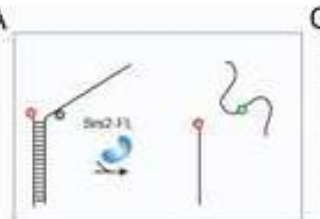

B

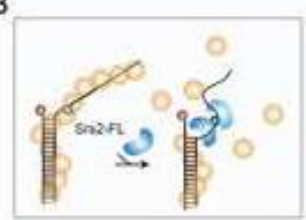

F Average unwinding time Sis2.FL

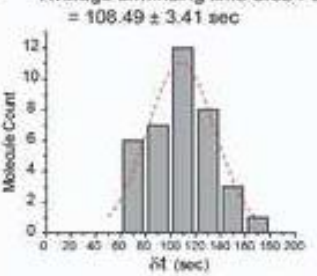

C

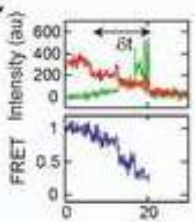

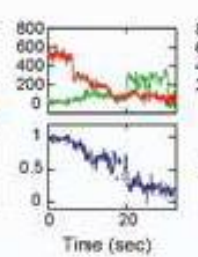

D
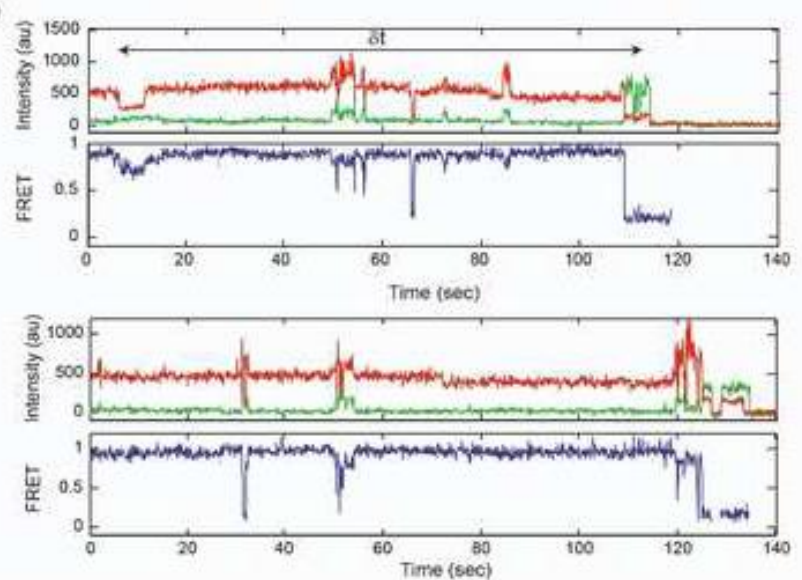

E 14.) Average unwinding tine Srs2-FL
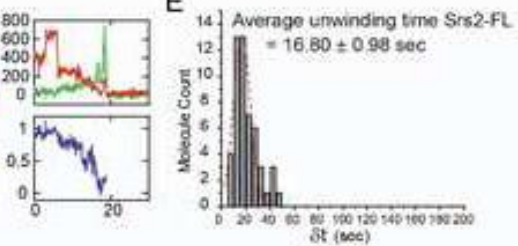
se
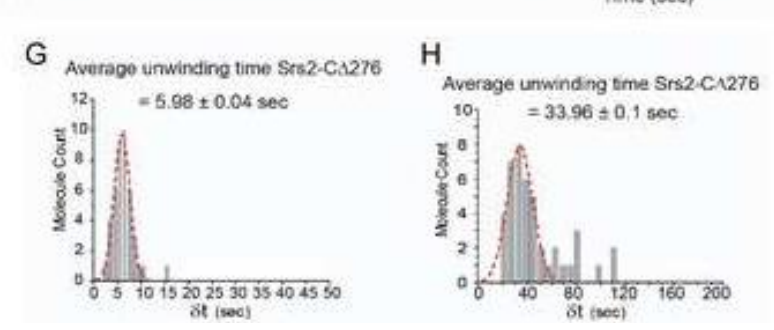

FIGURE 8. Rad51 dependent inhibition of DNA unwinding is observed for both the Srs2 ${ }^{\mathrm{FL}}$ and Srs2 ${ }^{\mathrm{C} \triangle 276}$ proteins in single molecule FRET analysis. (A, B) Schematic of unwinding DNA constructs used in this study showing an 18 bp dsDNA substrate with a 20 nt 3' overhang with Cy3 and Cy5 probes located near duplex junction. Upon DNA unwinding, a decrease in the FRET signal is observed. (C, D) Srs2 ${ }^{\mathrm{FL}}$ unwinding in the presence of Rad51 is delayed as indicated by slower FRET decrease than unwinding without Rad51. $(E, F)$ Histograms and Gaussian distribution fits show that the Srs2 ${ }^{\mathrm{FL}}$ unwinding duration is about 6 times longer in the presence of Rad51. $(\mathrm{G}, \mathrm{H})$ Histograms and Gaussian distribution fits show that the Srs2 ${ }^{\mathrm{C}} \Delta 276$ unwinding duration is about 5-6 times longer in the presence of Rad51. Errors in fit results are in s.e.m.. Rad51 retards the DNA unwinding time by $\sim 5.67$ and $\sim 6.45$ fold for Srs2 ${ }^{\mathrm{C} \Delta 276}$ and Srs $2^{\mathrm{FL}}$ proteins respectively. 
NOT THE PUBLISHED VERSION; this is the author's final, peer-reviewed manuscript. The published version may be accessed by following the link in the citation at the bottom of the page.

\section{Figure 9}

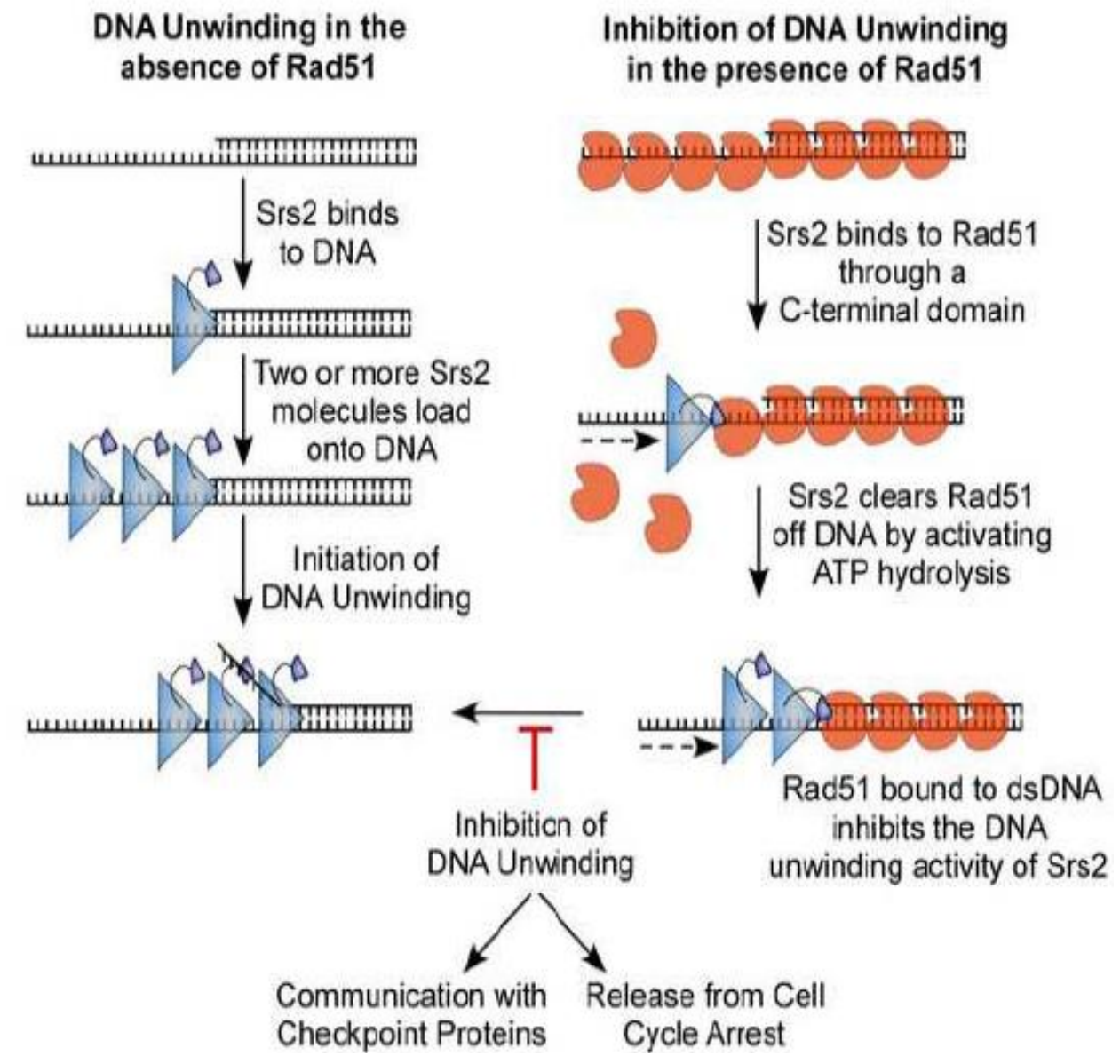

FIGURE 9. Context dependent regulation of Srs 2 activity by Rad51. Schematic representation depicts that two or more Srs2 molecules are required to unwind DNA. When Rad51 coats the dsDNA, its specific physical interaction with Srs2 inhibits the DNA unwinding activity. The same physical interaction is required to remove Rad51 molecules from the ssDNA. This context dependent regulation of Srs2's unwinding activity by Rad51 possibly regulates their activities in HR. 


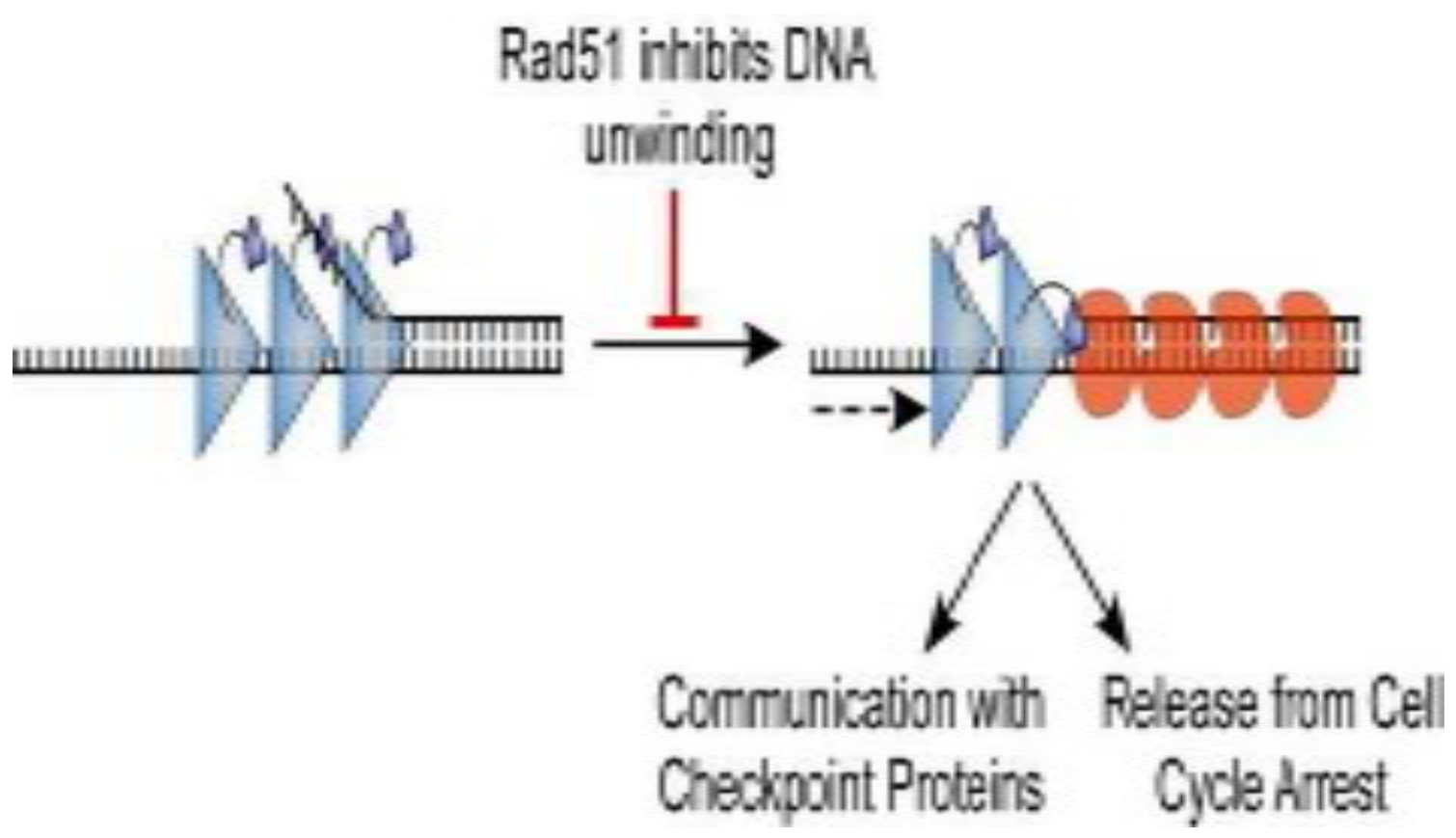

\footnotetext{
*To whom correspondence should be addressed:

Edwin Antony

Department of Chemistry and Biochemistry, Utah State University, Logan, UT 84322, USA

Tel.: (435) 797-1635; Fax: (435) 797-3390

Email: edwin.antony@usu.edu
} 